OPEN ACCESS

Edited by:

Isacco Ferrarini,

Brown University, United States

Reviewed by:

Giuseppe Broggi,

University of Catania, Italy

Biswa Biswal,

KPJ Ipoh Specialist Hospital, Malaysia

*Correspondence:

Meng Qiu

qiumeng@wchscu.cn

${ }^{\dagger}$ These authors have contributed equally to this work

Specialty section:

This article was submitted to Cancer Molecular Targets and Therapeutics, a section of the journal

Frontiers in Oncology

Received: 11 June 2021 Accepted: 25 August 2021 Published: 15 September 2021

Citation:

Wei G, Shu X, Zhou Y, Liu X, Chen X and Qiu M (2021) Intra-Abdominal

Desmoplastic Small Round Cell Tumor: Current Treatment Options and Perspectives.

Front. Oncol. 11:705760. doi: 10.3389/fonc.2021.705760

\section{Intra-Abdominal Desmoplastic Small Round Cell Tumor: Current Treatment Options and Perspectives}

\author{
Guixia Wei ${ }^{1 \dagger}$, Xinyao Shu ${ }^{1 \dagger}$, Yuwen Zhou ${ }^{2 \dagger}$, Xia Liu ${ }^{1}$, Xiaorong Chen ${ }^{1}$ and Meng Qiu ${ }^{1 *}$ \\ ${ }^{1}$ Department of Abdominal Cancer, Cancer Center, West China Hospital of Sichuan University, Chengdu, China, \\ ${ }^{2}$ Department of Biotherapy, Cancer Center, West China Hospital of Sichuan University, Chengdu, China
}

Intra-abdominal desmoplastic small round cell tumor (IDSRCT) is a rare and highly malignant soft tissue neoplasm, which is characterized by rapid progression and poor prognosis. The mechanism underlying the development of this neoplasm remains elusive, but all cases are characterized by the chromosomal translocation t $(11 ; 22)$ (p13; q12), which results in a formation of EWSR1-WT1 gene fusion. The diagnosis of IDSRCT is often made with core-needle tissue biopsy specimens or laparoscopy or laparotomy. Immunohistochemical analyses have shown the co-expression of epithelial, neuronal, myogenic, and mesenchymal differentiation markers. FISH or reverse transcription polymerase chain reaction detecting EWS-WT1 fusion can be performed to assist in molecular confirmation. There is no standard of care for patients with IDSRCT currently, and majority of newly diagnosed patients received the aggressive therapy, which includes $>90 \%$ resection of surgical debulking, high-dose alkylator-based chemotherapy, and radiotherapy. More recently, targeted therapy has been increasingly administered to recurrent IDSRCT patients and has been associated with improved survival in clinical conditions. Immunotherapy as a possible therapeutic strategy is being explored in patients with IDSRCT. In this review, we summarize currently available knowledge regarding the epidemiology, potential mechanisms, clinical manifestations, diagnosis, treatment, and prognosis of IDSRCT to assist oncologists in comprehensively recognizing and accurately treating this malignancy.

Keywords: intra-abdominal desmoplastic small round cell tumor, EWS-WT1 gene, treatment, targeted therapy, immunotherapy

\section{INTRODUCTION}

Desmoplastic small round cell tumor (DSRCT), according to the International Classification of Disease for Oncology (2020), is categorized as a malignant tumor of uncertain differentiation. DSRCT typically occurs in the abdominal cavity, which is known as intra-abdominal desmoplastic small round cell tumor (IDSRCT) (1). Other primary sites have been reported (Figure 1). It is a rare and aggressive malignant soft tissue sarcoma that predominantly occurs in young male adults (20). IDSRCTs are associated with chromosomal translocation $\mathrm{t}(11 ; 22)$ (p13; q12), which results in a formation of EWSR1-WT1 gene fusion $(21,22)$. IDSRCT mainly originates in the abdominopelvic cavity, involving 


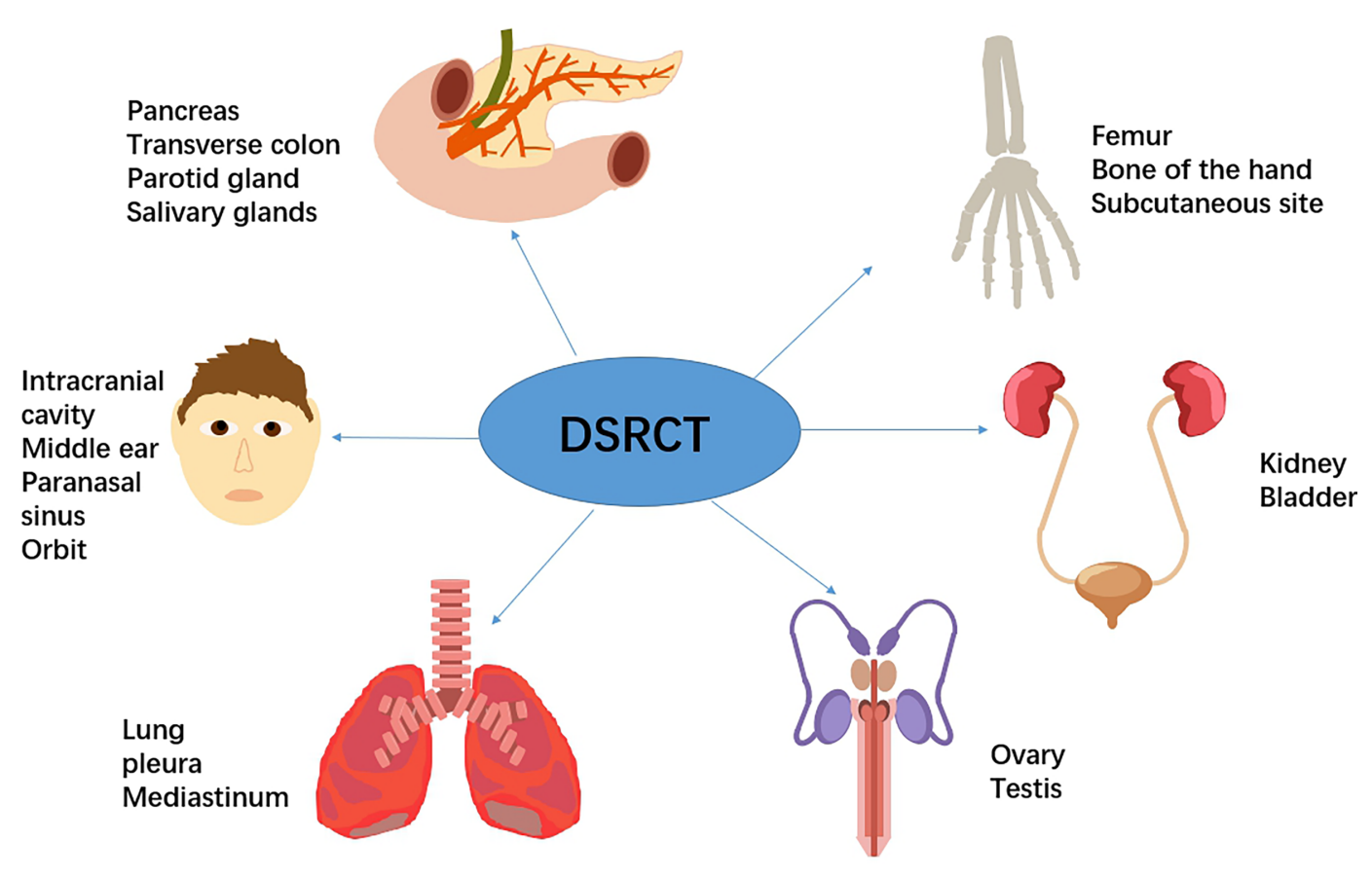

FIGURE 1 | Previous case reports reported primary sites of DSRCT, including kidney (2), bladder (3), pancreas (4), transverse colon (5), testes (6), ovary (7), mediastinum (8), pleura (9), lung (10), parotid gland (11), salivary glands (12), middle ear (13), sinonasal (14), orbital (15), intracranial cavity (16), subcutaneous site (17), femur (18), and bone of the hand (19).

the mesentery and retroperitoneum $(23,24)$. There is a lack of international consensus regarding the treatment of IDSRCT, and therapeutic regimens were derived from Ewing sarcoma's (ES) treatment because of the involvement of the EWS gene and activation of similar oncogenic pathways in both ES and IDSRCT. The prognosis of IDSRCT is poor, with a median 5year survival rate of $15 \%-25 \%$ (25). Because of the rarity of this malignancy, very few studies have investigated it, and most of these studies are case reports. This review summarizes the current knowledge on the epidemiology, potential mechanisms, clinical manifestations, diagnosis, treatment, and prognosis of IDSRCT, highlighting the modalities of treatment.

\section{METHODS}

This review summarizes the available literature on IDSRCT. We used the terms "abdominal," "desmoplastic small round cell tumor," and "intra-abdominal desmoplastic small round cell tumor" in our literature search. Previous reviews, articles, clinical trials, and case reports were included, and our search was not limited by language. Studies published from 1989 to 2021 were analyzed in the current review.

\section{EPIDEMIOLOGY}

IDSRCT is a rare and aggressive soft-tissue sarcoma. Its morbidity ranges between 0.2 and 0.74 cases per million people per year (26-28). IDSRCT mainly affects adolescents or young adults (median age at diagnosis: 27.0 years; range: 16-45 years), with a marked predominance in males (4:1 male-tofemale ratio) $(29,30)$. No specific risk factors associated with the occurrence or progression of IDSRCT have been reported.

\section{MECHANISM}

The pathogenesis of IDSRCT remains elusive. However, it is uniquely characterized by chromosomal translocation $t(11 ; 22)$ (p13; q12), which results in the fusion of the EWS and WT1 genes. The wild-type WT1 gene encodes a zinc finger-containing protein, which acts as a repressor of transcription. With the fusion of the EWS and WT1 genes, the normal function of the zinc finger region of the WT1 gene is lost, leading to the transcriptional activation of at least 35 downstream target genes $(31,32)$. These target genes encode growth factors and growth factor receptors, such as platelet-derived growth factor (PDGF)- $\alpha$, Type- 1 insulinlike growth factor receptor (IGF-1-R), and epidermal growth factor receptor (EGFR) (33), which are related to tissue differentiation and the proliferation, adhesion, and metastasis of the tumor cells (34).

Recent genomics analysis of mutational profiles indicated that epithelial-mesenchymal transition (EMT), immune response, and the DNA damage response (DDR) are associated with gene deregulation in DSRCT (35). Whole-exome sequencing of six consecutive pre-treated DSRCT samples identified 137 unique somatic mutations: 133 mutated genes were case- 
specific, and only 2 genes were overlapping among two cases but in different locations, which reveals the heterogeneity of the DSRCT genome. They also discovered that $27 \%$ of the 135 mutated genes are associated with DDR and EMT/ mesenchymal-epithelial reverse transition (MErT), which could result in tumor extreme heterogeneity followed by genomic instability, and consequently produce drug resistance (35). MErT/EMT plays a crucial role in the metastasis and associated invasiveness of the sarcoma (36). Jiang et al. reported two novel somatic mutations, one associated with cMet tyrosine kinase and the other related to PIK3CA gene, in 10 advanced stage DSRCT patients (37). The latter mutation was involved in the activation of the $\mathrm{PI} 3 \mathrm{~K} / \mathrm{AKT} / \mathrm{mTOR}$ pathway, facilitating the growth and proliferation of tumor cells (38).

\section{CLINICAL MANIFESTATIONS}

IDSRCT is commonly diagnosed at an advanced stage. Enlarged lymph nodes were seen in $50 \%$ of the patients, and distant metastasis was reported in $25 \%$ of the cases at the time of diagnosis (39). Widespread tumor nodules were also observed throughout the peritoneum, especially in the mesentery or omentum (40) (Table 1). The most common extraperitoneal metastasis is liver, followed by lymph node, bones, and lung (27, 28). The manifestations of IDSRCT are nonspecific and are related to the size, location, and speed of disease progression $(40,70,71)$. It usually presents as a palpable abdominal mass with pain and other diverse symptoms, including distention, ascites, loss of weight, jaundice, fatigue, and constipation (Figure 2). Huge tumor masses can also cause compression symptoms, like intestinal obstruction and ureteral obstruction (72).

\section{DIAGNOSIS}

The diagnosis of IDSRCT is often made with core-needle tissue biopsy specimens or laparoscopy or laparotomy (73). IDSRCT is thought to originate from progenitor cells with polyphenotypic potential (38). Macroscopically, IDSRCT is visible as a pale and firm mass in the peritoneal cavity with or without hemorrhage, necrosis, and cystic degeneration (20). Microscopically, histological examination shows uniform small round tumor cells grouped as clumps and nests with unclear cell borders, hyperchromatic nuclei, and inconspicuous nucleoli surrounded by hypocellular desmoplastic stroma. Glandular or rosette patterns or nuclear molding can be discovered. In addition, mitosis and apoptosis are common $(71,74,75)$. However, a recent case report described a 12-year-old boy of IDSRCT characterized by spindle cells with scant cytoplasm and with no desmoplastic stromal reaction, which reveals the heterogeneity of morphologic features in IDSRCT (72). Immunohistochemical analyses of IDSRCT have shown the co-expression of epithelial (cytokeratin and epithelial membrane antigen), neuronal (NSE and CD56), myogenic (desmin), and mesenchymal (vimentin) differentiation markers and WT1 (C-terminus antibody) (Table 2). Notably,
$>90 \%$ of patients with DSRCT express desmin and EMA (80). Most IDSRCT patients typically do not express CD 99, HMB-45, S-100, and myogenin $(75,81)$.

As for molecular characteristics of DSRCT, previous literature described that almost all DSRCTs exhibit nuclear positivity for the DNA binding domain (C-terminal portion) of WT1, which can distinguish DSRCT from Wilms tumor and Ewing sarcoma (80). The specific chromosomal translocation $\mathrm{t}(11 ; 22)$ (p13; q12) of DSRCT produces a chimeric EWSR1-WT1 fusion gene that encodes an aberrant transcription regulatory factor consisting of the C-terminal portion of WT1 and the trans-activation domain (N-terminal portion) of EWS (72). The EWSR1-WT1 fusion gene generally consists of exon 7 of the EWSR1 gene on chromosome 22 and exons 8-10 of the WT1 gene on chromosome 11 (82). However, several studies reported various alternative breakpoints for the $\mathrm{t}(11 ; 22)$ (p13; q12) translocation $(72,83-85)$. Those fusion gene variants generally contain additional exons from EWS with conservation of the WT1 complement (EWS-WT1 8/8, 9/8, 10/8, and 9/7). Due to the heterogeneity of immunohistochemical findings, molecular methods are essential to verify diagnosis of IDSRCT (86). Molecular analysis by fluorescence in situ hybridization (FISH) and reverse transcription polymerase chain reaction to detect EWSR1 rearrangement and the EWSR1-WT1 fusion gene, respectively, has also been used to confirm IDSRCT diagnosis along with clinical findings (86). The molecular methods have higher sensitivity than that of immunohistochemical tools (87).

No specific tumor markers have been identified for the diagnosis of IDSRCT, except elevated serum CA125 and NSE levels in some patients $(3,57,71)$. For imaging information, ultrasound usually shows lobulated peritoneal masses with variable echogenicity, and dystrophic intratumoral calcification is discovered in $20 \%$ of cases (75). Computed tomography (CT) is considered as a primary auxiliary method for the assessment of response and follow-up of IDSRCT, which typically show multifocal masses originating from the retroperitoneum or abdominopelvic cavity with poorly defined boundaries and unevenly enhanced signals. Cystic changes in large masses with heterogeneous enhancement can be found after contrast. Some cases had evidence of punctate calcification in primary mass (34, $88,89)$. Twenty percent of IDRCT patients show ascites, and lymph node involvement can be seen in $50 \%$ of cases (75). Magnetic resonance imaging (MRI) can detect potential lesions that are not observed by CT alone. Due to the presence of necrosis, hemorrhage, and fibrous stroma in IDSRCT, it often shows heterogeneous high-intensity signals on T2-weighted images and hypointense or isointense signals on T1-weighted images in MRI with heterogeneous enhancement after gadolinium $(74,75)$. Although CT and MRI can help to identify primary sites of IDSRCT, they have limited power to show the metabolic activity of tumors, which promotes the application of 18F-fluorodeoxyglucose (FDG) positron emission tomography (PET) and CT (FDG PET/CT) in IDSRCT (90). A retrospective study indicated that FDG-PET may earlier predict histologic response to chemotherapy than macroscopic size change detected by CT. Although most patients 
TABLE 1 | Published case reports and case series regarding IDSRCT.

\begin{tabular}{|c|c|c|c|c|c|c|c|c|}
\hline Reference & Patient & Diagnosis & Metastases & Treatment & Regimen & Response & PFS (m) & OS (m) \\
\hline (41) & $F / 46$ & Resection biopsy & Omentum & $\mathrm{C}+\mathrm{S}$ & HD-CAV & $\mathrm{SD}$ & 1 & NR \\
\hline (42) & $\mathrm{M} / 10$ & Resection biopsy & Liver, lung & $\mathrm{C}+\mathrm{R}$ & $\mathrm{VI}$ & PR & 46 & 50 \\
\hline (4) & $\mathrm{M} / 9$ & Resection biopsy & $\mathrm{NR}$ & $\mathrm{S}+\mathrm{C}$ & VAl & NR & 7 & NR \\
\hline (43) & $F / 23$ & Biopsy & Liver lymph nodes & C & VDC & PD & NR & 4 \\
\hline$(44)$ & $\mathrm{M} / 26$ & Biopsy & Pelvic & $\mathrm{C}+\mathrm{S}+\mathrm{H}+\mathrm{R}$ & VDC/IE & $\mathrm{CR}$ & 48 & NR \\
\hline (45) & $\mathrm{M} / 18$ & Fine-needle aspiration & NR & $\mathrm{C}+\mathrm{S}+\mathrm{T}$ & Trabectedin & PR & 8 & 48 \\
\hline (46) & $\mathrm{M} / 14$ & Biopsy & Liver, spleen, kidney, pancreas & $\mathrm{C}+\mathrm{S}+\mathrm{R}$ & VDC/IE & $\mathrm{SD}$ & NR & NR \\
\hline$(47)$ & $M / 14$ & Resection biopsy & Liver & $\mathrm{S}+\mathrm{C}$ & NR & Improved & NR & NR \\
\hline (48) & $\mathrm{M} / 27$ & Biopsy & Spleen, lymph node & $\mathrm{C}+\mathrm{S}$ & VDC/IE & Improved & NR & NR \\
\hline (49) & $\mathrm{M} / 24$ & Resection biopsy & Lymph node, omentum & $\mathrm{C}+\mathrm{S}$ & IMAP & Death & 0 & NR \\
\hline$(50)$ & $\mathrm{M} / 21$ & Biopsy & Liver, lleum, cecum & $\mathrm{C}+\mathrm{S}$ & VDC/IE & $\mathrm{SD}$ & 12 & NR \\
\hline (51) & M/39 & Biopsy & Lymph node & $\mathrm{C}+\mathrm{S}$ & VDC/IE & SD & NR & NR \\
\hline$(52)$ & $\mathrm{M} / 16$ & NR & Prostate, rectum & $\mathrm{C}+\mathrm{S}+\mathrm{R}$ & VNR-CTX & PR & 17 & NR \\
\hline (53) & $\mathrm{M} / 26$ & Biopsy & Liver, lymph node & $\mathrm{C}$ & VNR-CTX & PR & 4 & NR \\
\hline (53) & $\mathrm{M} / \mathrm{NR}$ & NR & Bone, lymph nodes, liver & $\mathrm{T}$ & Sunitinib & $\mathrm{SD}$ & 10 & NR \\
\hline (53) & $\mathrm{M} / \mathrm{NR}$ & NR & Lymph nodes, peritoneum & $\mathrm{T}$ & Sunitinib & SD & 4 & NR \\
\hline (53) & $\mathrm{M} / \mathrm{NR}$ & NR & Peritoneum, lymph node & $\mathrm{T}$ & Sunitinib & $\mathrm{SD}$ & 6 & NR \\
\hline (53) & $\mathrm{M} / \mathrm{NR}$ & NR & Liver, peritoneum & $\mathrm{T}$ & Sunitinib & PD & 1 & NR \\
\hline (53) & $\mathrm{M} / \mathrm{NR}$ & NR & Liver, pleura, peritoneum & $\mathrm{T}$ & Sunitinib & PD & 1 & NR \\
\hline (53) & $\mathrm{M} / \mathrm{NR}$ & NR & Liver, lung, peritoneum & $\mathrm{T}$ & Sunitinib & PD & 2 & NR \\
\hline (53) & $\mathrm{M} / \mathrm{NR}$ & NR & Liver, peritoneum & $\mathrm{T}$ & Sunitinib & PR & 10 & NR \\
\hline (53) & $\mathrm{M} / \mathrm{NR}$ & NR & Peritoneum, lymph node & $\mathrm{T}$ & Sunitinib & PR & NR & NR \\
\hline (54) & $\mathrm{M} / 23$ & Biopsy & Liver, peritoneum & $\mathrm{C}+\mathrm{S}$ & VDC/IE+ Trabectedin & $\mathrm{SD}$ & NR & 24 \\
\hline (54) & $\mathrm{M} / 19$ & $\mathrm{NR}$ & Liver, pleura, peritoneum & C & VDC/IE+ Trabectedin & SD & NR & 16 \\
\hline (5) & $\mathrm{F} / 30$ & Resection biopsy & No & S & No & $\mathrm{SD}$ & 6 & NR \\
\hline (55) & $M / 31$ & Resection biopsy & Brain, liver, lymph nodes & $\mathrm{S}+\mathrm{C}+\mathrm{R}$ & NR & PD & NR & 17 \\
\hline (56) & $\mathrm{M} / 27$ & Tissue biopsy & Mesentery, peritoneum. & $\mathrm{C}$ & PAVEP & PR & NR & 12 \\
\hline (57) & $\mathrm{F} / 22$ & Frozen biopsy & NR & C & 1.VDC2.VAC & PD & NR & 9 \\
\hline (58) & $\mathrm{M} / 18$ & Percutaneous biopsy & Mesentery, liver & C & VDC/IE +irinotecan & PR & NR & 20 \\
\hline (59) & $\mathrm{NR} / \mathrm{NR}$ & $\mathrm{NR}$ & NO & $\mathrm{C}+\mathrm{T}$ & Pazopanib+ sirolimus & $\mathrm{SD}$ & NR & NR \\
\hline (60) & $\mathrm{F} / 11$ & Resection biopsy & Ovary & $\mathrm{S}+\mathrm{C}$ & VDC/IE & PD & NR & 11 \\
\hline (61) & $\mathrm{F} / 7$ & Resection biopsy & NO & $\mathrm{S}+\mathrm{C}$ & VDIE+VP-16 & $\mathrm{SD}$ & NR & NR \\
\hline (62) & $M / 38$ & Biopsy & Vessels, colon lymph nodes & $\mathrm{S}+\mathrm{R}+\mathrm{C}$ & CAP & $\mathrm{CR}$ & 30 & NR \\
\hline (63) & $\mathrm{F} / 30$ & Frozen biopsy & Ovary, lung, lymph node & $\mathrm{S}+\mathrm{C}$ & VDC & PR & NR & NR \\
\hline (64) & $M / 52$ & Biopsy & Omentum & C & VDC/IE & Death & NR & NR \\
\hline (65) & $\mathrm{M} / 16$ & Biopsy & Colon, stomach, spleen & $S$ & NO & $\mathrm{SD}$ & NR & NR \\
\hline (66) & $\mathrm{M} / 33$ & Biopsy & NR & C & ICE & SD & NR & NR \\
\hline (30) & $\mathrm{M} / 11$ & Biopsy & NR & $\mathrm{C}+\mathrm{S}$ & VAC/IVA & PR & NR & NR \\
\hline (30) & $\mathrm{M} / 7$ & Resection, biopsy & Omentum, bowel, pelvis & $\mathrm{S}+\mathrm{C}$ & IRS-38 & SD & 18 & NR \\
\hline (30) & $F / 13$ & Biopsy & Small bowel & $\mathrm{C}+\mathrm{S}+\mathrm{SCT}$ & IRS-38 & NR & 9 & 11 \\
\hline (30) & $\mathrm{M} / 11.5$ & Resection biopsy & Liver, bladder, colon & $\mathrm{S}+\mathrm{C}$ & G-FLIP & NR & 8 & NR \\
\hline (67) & $F / 26$ & Biopsy & Pancreas, vein, duodenum & C & VDC/IE & $\mathrm{SD}$ & NR & 9 \\
\hline$(68)$ & $\mathrm{M} / 22$ & Resection biopsy & Liver, peritoneum & C & $\mathrm{DC}$ & PR & NR & 13 \\
\hline (69) & $\mathrm{M} / 29$ & Resection biopsy & Small bowel, lymph node & $\mathrm{S}+\mathrm{C}+\mathrm{R}$ & VDC/IE & Improved & NR & NR \\
\hline
\end{tabular}

IDSRCT, intra-abdominal desmoplastic small round cell tumor; $C$, chemotherapy; S, surgery; $R$, radiotherapy; $T$, target therapy; H, HIPEC; SD, stable disease; CR, complete response; PR, partial response; PD, progressive disease; $M$, male; $F$, female; EVAIA, etoposide, vincristine, doxorubicin, ifosfamide, and dactinomycin; VAC/IE, vincristine, actinomycin D, and cyclophosphamide, then alternated with ifosfamide and etoposide; IMAP, vincristine, doxorubicin, ciclofosfamida, isofosfamida, etoposide; VAl, ifosfamide, doxorubicin, vincristine; VDC, vincristine, doxorubicin, cyclophosphamide; PAVEP, cyclophosphamide, etoposide, doxorubicin, cisplatin; VI, irinotecan, vincristine; IT, irinotecan, temozolomide; PC, carboplatin, paclitaxel; DC, doxorubicin, cisplatin; VDIE, vincristine, doxorubicin, etoposide, ifosfamide; CAP, cyclophosphamide, adriamycin, cisplatin; ICE, IFM, etoposide, carboplatin; IVA, actinomycin-D, vincristine, ifosfamide; IRS-38, oncovin, platinol, adriamycin, cyclophosphamide; G-FLIP, Gemzar, 5-FU/leucovorin, camptothecin, platinol; SCT, blood stem cell transplantation; NR, not reported.

obtain rapid symptom relief when treated with chemotherapy, the change of tumor size is generally minimal because of the presence of abundant stromal component in IDSRCT, while the great decrease of metabolic activity can be detected by FDG-PET earlier (91). Furthermore, the specificity of FDG PET/CT is as high as $\mathbf{9 7 . 4 \%}$ in DSRCT lesions, especially for involved lymph node and bone metastatic lesions, allowing early discovery of recurrent IDRCT and change of treatment strategy (90, 92, 93). Thus, FDG PET-CT should be considered as the preferred imaging method for monitoring patients with IDSRCT (90).

\section{STAGING}

There is no definite staging system for IDSRCT. Green et al. (94) proposed a staging system based on primary tumor burden, liver metastasis, and extra-abdominal metastasis. Primary tumor burden was measured using the peritoneal cancer index (PCI) score, calculated by measuring the tumor diameter in 13 abdominopelvic regions (95). In this staging system, a lower PCI score $(<12)$ without liver or extra-abdominal metastasis was defined as Stage I; a higher PCI score $(\geq 12)$ without liver or 


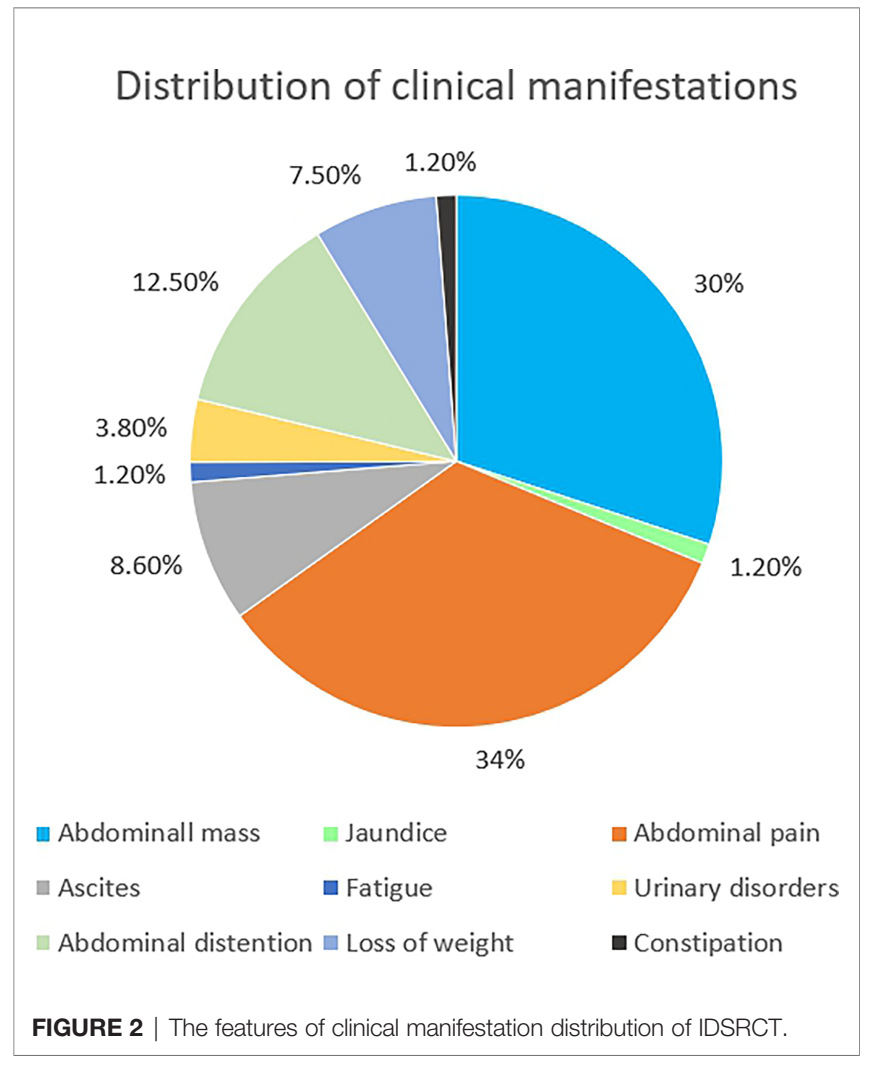

extra-abdominal metastasis was defined as Stage II; liver metastasis without extra-abdominal metastasis was defined as Stage III; and extra-abdominal metastasis regardless of PCI score was defined as Stage IV (Table 3). However, this staging system requires further validation before being applied to all DSRCT types.

\section{TREATMENTS}

The therapeutic regimen for IDSRCT is mainly derived from ES treatment because of the similarity in the oncogenic pathways involved and EWS gene fusion in both malignancies (31). Although multimodal treatments have been proposed for IDSRCT patients, the prognosis remains poor (96). With the widespread utilization of targeted therapy, the prognosis of IDSRCT patients has markedly improved. Published case reports and case series of treatments administered to IDSRCT patients are summarized in Table $\mathbf{1}$.

\subsection{Surgery}

Radical surgical excision without residual disease is usually impossible because of the presence of multiple serosal tumor nodules and obscure boundary of IDSRCT (97). Thus, cytoreductive surgery (CRS) is regarded as the fundamental therapy for IDSRCT patients, which is defined as the resection

TABLE 2 | The features of immunohistochemical staining of IDSRCT reviewed from published case reports and case series.

\begin{tabular}{|c|c|c|c|c|c|c|c|c|c|c|}
\hline & Vimentin & Desmin & EMA & CK & WT-1 & CD99 & Myogenin & $\mathbf{S 1 0 0}$ & NSE & Leu-7 \\
\hline Shen et al. (46) & NR & + & NR & + & + & - & - & - & NR & NR \\
\hline Shi et al. (76) & + & + & + & + & + & + & NR & - & + & NR \\
\hline Ambar et al. (42) & NR & + & + & + & + & - & NR & NR & NR & NR \\
\hline Li et al. (24) & NR & + & $+/-$ & $+/-$ & - & NR & NR & - & - & NR \\
\hline Reisner et al. (48) & NR & + & NR & + & NR & + & NR & + & NR & NR \\
\hline Briseño-Hernández et al. (49) & NR & + & + & NR & NR & NR & NR & NR & + & NR \\
\hline Kandhari et al. (50) & + & + & NR & + & NR & NR & NR & NR & NR & NR \\
\hline Nathan et al. (51) & NR & + & + & + & NR & NR & NR & + & + & NR \\
\hline Frezza et al. (54) & NR & + & NR & + & NR & NR & NR & - & NR & NR \\
\hline Frezza et al. (110) & NR & + & NR & - & - & NR & NR & - & - & NR \\
\hline Saleh et al. (4) & NR & NR & + & NR & NR & + & - & NR & NR & NR \\
\hline Huang et al. (5) & + & + & NR & + & + & NR & NR & NR & + & $N R$ \\
\hline Ordi (77) & + & + & + & + & NR & + & NR & NR & + & NR \\
\hline Takahira et al. (56) & + & + & $N R$ & + & NR & NR & NR & + & + & NR \\
\hline Wakahashi et al. (57) & + & + & + & - & NR & NR & NR & - & NR & NR \\
\hline Hirano et al. (58) & + & + & + & + & + & NR & NR & NR & NR & NR \\
\hline Slomovitz et al. (60) & NR & + & + & + & NR & NR & NR & - & NR & NR \\
\hline Eaton et al. (61) & NR & + & + & NR & + & + & - & NR & NR & NR \\
\hline Zhang et al. (62) & NR & + & + & - & NR & - & NR & $N R$ & NR & NR \\
\hline Ferreira et al. (44) & NR & + & + & NR & + & $N R$ & NR & NR & NR & NR \\
\hline Shimazaki (78) & NR & + & + & + & NR & + & NR & - & + & NR \\
\hline Kim et al. (67) & + & - & NR & - & NR & + & NR & NR & + & NR \\
\hline Devaney (79) & + & + & + & + & NR & NR & NR & $\mathrm{NR}$ & NR & NR \\
\hline Ujihara et al. (66) & NR & + & NR & + & - & NR & NR & - & NR & NR \\
\hline Takekawa et al. (65) & + & + & + & NR & + & NR & NR & NR & + & NR \\
\hline Baz et al. (64) & + & + & + & NR & + & - & NR & NR & NR & NR \\
\hline Xie et al. (63) & + & + & + & NR & NR & - & NR & $\mathrm{NR}$ & $N R$ & $N R$ \\
\hline
\end{tabular}

IDSRCT, intra-abdominal desmoplastic small round cell tumor; +, positive; -, negative; +/-, suspicious positive; NR, not reported; EMA, epithelial membrane antigen; CK, cytokeratin; NSE, neuron-specific enolase. 
of $\geq 90 \%$ of the tumor burden, preserving the non-invaded peritoneum macroscopically $(70,98)$. The lesions are generally confined to the serosal or superficial muscle layers, although there is dissemination throughout the peritoneal cavity, allowing the treatment of local tangential resection (99). The surgical resection extension is usually extensive, including the resection of primary disease with acceptable margins, peritonectomy, lymphadenectomy, and the resection of involved adjacent tissue (89). To preserve bowel length, wedge excision can be performed to remove masses that invade deeply into the bowel (99). According to the recent studies, patients treated with complete CRS have significantly improved survival compared with patients receiving insufficient or no surgery with macroscopic residual tumor (the 3-year survival rates $49.6 \% v s$. $31.1 \%$ vs. $13.7 \%, \mathrm{p}=0.009)(70,100)$. Complete resection of metastases combined with cytoreduction is essential in patients with extra-abdominal disease, while locoregional surgery alone typically cannot be considered if patients have extra-abdominal lesion. Moreover, it is not a first option for IDSRCT patients with extensive subdiaphragmatic lesion or unresectable periportal disease or widely infiltration or metastases of liver to received CRS (99). Based on the Sugarbaker completeness of cytoreduction (CR) score, the completeness of CRS was classified under four categories: CR 0, no macroscopically residual disease; CR 1, residual nodules smaller than $2.5 \mathrm{~mm}$; CR2, residual nodule size ranging from $2.5 \mathrm{~mm}$ to $2.5 \mathrm{~cm}$; and CR 3, residual nodule size larger than $2.5 \mathrm{~cm}$ (101). To achieve complete CRS, multivisceral resection is often needed, followed by various complications. Fifty-six percent of patients after surgery have mild complications, including urinary retention/ urinary tract infection, wound infection, and ileus, while pelvic abscess, AKI, respiratory failure, and anastomotic dehiscence were reported in the residual $44 \%$ of patients who received surgery (102). Therefore, extensive surgical resection-associated complications should be considered before the administration of surgery.

\subsection{Chemotherapy}

IDSRCT is sensitive to chemotherapy; therefore, neoadjuvant chemotherapy is usually recommended for patients with advanced-stage and unresectable IDSRCT (27). Several studies have suggested that IDSRCT patients who have evident efficacy to neoadjuvant chemotherapy have an improved overall survival (OS) than those who are resistant to neoadjuvant therapy (27, 103). However, IDSRCT treated with neoadjuvant chemotherapy may not have a significant reduction of size because of its large stromal component, which should not delay or prevent an

TABLE 3 | DSRCT staging criteria proposed by Hayes-Jordan, Green et.al.

\begin{tabular}{llll}
\hline Stage & $\begin{array}{c}\text { Primary } \\
\text { tumor (PCI) }\end{array}$ & $\begin{array}{c}\text { Liver } \\
\text { metastasis }\end{array}$ & $\begin{array}{c}\text { Extra-abdominal } \\
\text { metastasis }\end{array}$ \\
\hline I & $<12$ & No & No \\
II & $\geq 12$ & No & No \\
III & Any & Yes & No \\
IV & Any & Yes or no & Yes \\
\hline
\end{tabular}

DSRCT, desmoplastic small round cell tumor; $P C l$, peritoneal cancer index. attempt of administration of CRS (91). The chemotherapy regimen of IDSRCT mainly follows the same schedule as that used in ES (25). The P6 chemotherapy regimen, comprising vincristine/doxorubicin/cyclophosphamide alternating with etoposide/ifosfamide (VDC/IE), is the most common neoadjuvant chemotherapy regimen for IDSRCT patients (43, 69). Vincristine, doxorubicin, and ifosfamide are a reasonable alternative regimen for older people who may not tolerate the intense regimen (73). For P6 chemotherapy-resistant patients, temozolomide/irinotecan, cyclophosphamide/topotecan, gemcitabine/docetaxel, and high-dose ifosfamide can be considered as second- or third-line chemotherapy regimens (Table 4) $(75,80,104)$. Some IDSRCT patients receive adjuvant chemotherapy (high-dose 5-FU, temozolomide/ irinotecan-based therapy, and high-dose ifosfamide) (104-106) in combination with radiotherapy after CRS to increase the effectiveness of the surgery $(105,106)$. Palliative chemotherapy is administered to patients with metastatic tumors at the time of diagnosis (27). Several regimens, such as irinotecan in combination with vincristine (42), vinorelbine plus low-dose cyclophosphamide (52), and trabectedin $(45,54)$, have been reported to show clinical benefits for refractory IDSRCT patients. Specifically, trabectedin has been shown to interact with the minor groove of DNA, affecting several transcription

TABLE 4 | The common chemotherapeutic regimens for the treatment of DSRCT.

\begin{tabular}{|c|c|c|}
\hline Regimen & Agent & Dose \\
\hline \multicolumn{3}{|l|}{ First-line } \\
\hline \multirow[t]{5}{*}{ VDC/IE } & Vincristine & $1.5 \mathrm{mg} / \mathrm{m}^{2}$ \\
\hline & Doxorubicin & $37.5 \mathrm{mg} / \mathrm{m}^{2}$ \\
\hline & Cyclophosphamide & $1,200 \mathrm{mg} / \mathrm{m}^{2}$ \\
\hline & Etoposide & $100 \mathrm{mg} / \mathrm{m}^{2}$ \\
\hline & Ifosfamide & $1,800 \mathrm{mg} / \mathrm{m}^{2}$ \\
\hline \multirow[t]{3}{*}{ VDI } & Vincristine & $1.5 \mathrm{mg} / \mathrm{m}^{2}$ \\
\hline & Doxorubicin & $37.5 \mathrm{mg} / \mathrm{m}^{2}$ \\
\hline & Ifosfamide & $1,800 \mathrm{mg} / \mathrm{m}^{2}$ \\
\hline VDIE & Vincristine & $1.5 \mathrm{mg} / \mathrm{m}^{2}$ \\
\hline \multirow[t]{7}{*}{ PAVEP } & Doxorubicin & $20 \mathrm{mg} / \mathrm{m}^{2}$ \\
\hline & Ifosfamide & $3,000 \mathrm{mg} / \mathrm{m}^{2}$ \\
\hline & Etoposide & $150 \mathrm{mg} / \mathrm{m}^{2}$ \\
\hline & Cyclophosphamide & 300 mg/m² \\
\hline & Etoposide & $75 \mathrm{mg} / \mathrm{m}^{2}$ \\
\hline & Doxorubicin & $40 \mathrm{mg} / \mathrm{m}^{2}$ \\
\hline & Cisplatin & $100 \mathrm{mg} / \mathrm{m}^{2}$ \\
\hline \multicolumn{3}{|c|}{ Second-line } \\
\hline & Temozolomide/irinotecan & NR \\
\hline & Cyclophosphamide/topotecan & NR \\
\hline \multirow[t]{3}{*}{ GD } & Gemcitabine & $1,000 \mathrm{mg} / \mathrm{m}^{2}$ \\
\hline & Docetaxel & $100 \mathrm{mg} / \mathrm{m}^{2}$ \\
\hline & High-dose ifosfamide & NR \\
\hline \multirow[t]{3}{*}{ VIP } & Etoposide & NR \\
\hline & Ifosfamide & NR \\
\hline & Cisplatin & NR \\
\hline \multicolumn{3}{|l|}{ HIPEC } \\
\hline & Cisplatin & $100 \mathrm{mg} / \mathrm{m}^{2}$ \\
\hline & Oxaliplatin & $300-460 \mathrm{mg} / \mathrm{m}^{2}$ \\
\hline \multirow[t]{2}{*}{$\mathrm{MC}$} & Mitomycin & $75 \mathrm{mg} / \mathrm{m}^{2}$ \\
\hline & Cisplatin & $120 \mathrm{mg}$ \\
\hline
\end{tabular}

DSRCT, desmoplastic small round cell tumor; NR, not reported. 
factors, DNA repair molecules, and DNA-binding proteins; perturbing the cell cycle; and subsequently causing the death of cancer cells (107). Trabectedin has been deemed safe and effective in pre-treated IDSRCT patients who were refractory to conventional chemotherapy and resection $(45,54)$.

Other special chemotherapy forms, such as hyperthermic intraperitoneal chemotherapy (HIPEC), are also considered in patients with extensive metastasis over the abdominal cavity (70). However, the role of HIPEC remains controversial. A previous retrospective study has reported a significant improvement in the 3 -year OS of patients treated with surgery and HIPEC (94), and other studies have shown that CRS followed by HIPEC may improve the disease control rate (DCR) in patients with peritoneal surface metastasis (106). Conversely, some studies have suggested that HIPEC is not associated with a better outcome $(27,70)$. Few patients who received CRS and HIPEC have been reported to need long-term parenteral nutrition or surgical intervention due to severe side effects, such as hemorrhagic cystitis, adhesive bowel obstruction, and sclerosing peritonitis (108). Therefore, assessing the actual effectiveness of HIPEC requires further studies.

\subsection{Radiotherapy}

Because of the multicentric growth tendency in the abdominopelvic cavity of IDRCT, whole-abdominopelvic radiotherapy (WAP RT) is a more effective treatment than locoregional radiotherapy (93). WAP RT is occasionally used as a consolidative therapy after CRS to remove microscopic or minimal residual disease $(<2 \mathrm{~cm})(88,99)$. Treatment is performed with megavoltage photon beams by AP/PA fields into the entire peritoneal cavity. The median dose for patients without residual disease is $30 \mathrm{~Gy}$ in 1.5-1.55 Gy fractions, while for patients with residual lesions, the dose can be increased to 45-50 Gy (70, 99). IDSRCT patients treated with WAP RT combined with CRS and chemotherapy experienced prolonged survival (104). As for complications, gastrointestinal and hematological toxicities were the most common reported acute complications, while small bowel obstruction was the most common late toxicity in IDSRCT patients who underwent WAP RT (109). Acute complications can be treated with supportive care or symptomatic treatment, while surgical intervention is required in up to $10 \%$ of small bowel obstruction (106). Patients subjected to intensity-modulated radiation therapy (IMRT) reported a lower incidence of hematological toxicities compared to those who underwent WAP-RT (109). IMRT was found to selectively decrease the irradiated doses of adjacent normal organs (e.g., liver, kidneys, and pelvis), allowing even dose distribution to the peritoneal surfaces (106). Furthermore, there is no significant difference in OS between patients treated with IMRT and WART (109). In addition to being used as an adjunctive treatment, radiation can also be administered as a palliative treatment for recurrent IDSRCT (104).

\subsection{Targeted Therapy}

The formation of EWSR1-WT1 fusion gene can activate downstream signaling pathways, including platelet-derived growth factor (PDGF), vascular endothelial growth factor (VEGF), and insulin growth factor (IGF)-1. Those pathways may be potential targets for treatment of IDSRCT (38). Until now, targeted therapy has shown its clinical benefit in IDSRCT patients who had tumor relapse or progression despite first-line or second-line treatment (38). Based on previous studies, tyrosine kinase inhibitors (TKI), including pazopanib (110), sunitinib (53), sorafenib (23), anlotinib (104), apatinib (76), imatinib (111), anti-VEGFR monoclonal antibody (e.g., bevacizumab) (68), IGF-1-R inhibitors (112, 113), mTOR inhibitors (114), and PARP inhibitors (100) were used for the therapies and were found to be effective in select IDSRCT cases. Targeted therapy-treated patients who were reviewed from case reports/series and our hospital are listed in Table 5. All ongoing clinical trials are summarized in Table 6.

\subsubsection{Pazopanib}

Pazopanib, a TKI, targets the stem cell factor receptor c-Kit, PDGFR- $\alpha$ and $-\beta$, and VEGFR-1, 2, and 3 to prohibit angiogenesis and tumor proliferation (117). Pazopanib has been approved by the U.S. Food and Drug Administration (FDA) and the European Medicines Agency for the treatment of patients with renal cell carcinoma (RCC) and sarcoma (118). IDSRCT overexpresses VEGF-A, VEGFR-2, and PDGF, which gives rationality to the administration of pazopanib in pretreated IDSRCT patients $(119,120)$. Pazopanib has been demonstrated to achieve a variable DCR of $61 \%$ and $78 \%$ for patients who received prior chemotherapy and those who did not, respectively. Median progression-free survival (PFS) of 9.2 months and OS of 15.4 months have also been observed with pazopanib treatment. The common adverse reactions following this treatment were neutropenia, hypertension, fatigue, and diarrhea $(110,121)$.

\subsubsection{Sunitinib}

Sunitinib has a mechanism of action like that of pazopanib, and it targets PDGFR, VEGFR, c-KIT, RET, colony-stimulating factor 1, and Flt3 (122). The FDA has approved sunitinib for the management of imatinib-refractory gastrointestinal stromal tumors (GISTs), RCC, and pancreatic neuroendocrine tumor (123). This agent has also shown clinical effectiveness in pretreated IDSRCT patients. In a case series comprising eight patients, six pretreated IDSRCT patients achieved an improved clinical outcome (partial remission $[\mathrm{PR}]$ and stable disease [SD]) after sunitinib treatment, and no severe adverse response was reported (53).

\subsubsection{Sorafenib}

Sorafenib, a multitargeted TKI, targets c-KIT, PDGFR- $\beta$, VEGFRs 2-3, and Flt-3. Sorafenib has been approved for treating hepatocellular carcinoma, RCC, and thyroid cancer (124). In a retrospective study, two progressive IDSRCT patients received sorafenib and progressed at 4 months. Of the two patients, one developed skin toxicity, while the other had to terminate the treatment due to severe abdominal pain (grade $=3$ ) (23). The true efficacy of sorafenib treatment for DSRCT patients requires large sample data to further validate the results. 
TABLE 5 | Retrospectivec cases from published reports and our hospital of IDSRCT patients treated with target therapy

\begin{tabular}{|c|c|c|c|c|c|c|c|c|c|c|}
\hline Reference & Patient & 1-line therapy & 2-line therapy & 3-line therapy & 4-line therapy & $\begin{array}{l}\text { 5-line } \\
\text { therapy }\end{array}$ & $\begin{array}{l}\text { 6-line } \\
\text { therapy }\end{array}$ & Response & $\begin{array}{l}\text { T-PFS } \\
(\mathrm{m})\end{array}$ & $\begin{array}{l}\text { OS } \\
(\mathrm{m})\end{array}$ \\
\hline (115) & $31 / \mathrm{M}$ & Gemcitabine+ nedaplatin & $\begin{array}{l}\text { Cyclophosphamide-epirubicin- } \\
\text { vincristine } \\
\text { Apatinib }\end{array}$ & NA & NA & NA & NA & PR & $N R$ & NR \\
\hline (76) & $32 / \mathrm{M}$ & Apatinib & NA & NA & NA & NA & NA & Improved & NR & NR \\
\hline (68) & $37 / M$ & PCB+ bevacizumab & NA & NA & NA & NA & NA & PR & NR & 34 \\
\hline (23) & NR & MAID-ASCT & Gemcitabine-cisplatin & Sunitinib & NA & NA & NA & NR & 2 & NR \\
\hline (23) & NR & $\begin{array}{l}\text { VAl-Adriamycin- cisplatin- etoposide- } \\
\text { cyclophosphamide }\end{array}$ & Carboplatin-etoposide & Sunitinib & NA & NA & NA & NR & 5.5 & NR \\
\hline (23) & NR & Cyclophosphamide-etoposide- carboplatin & $\begin{array}{l}\text { Etoposide-carboplatin-busulfan- } \\
\text { thiotepa }\end{array}$ & Temozolomide & $\begin{array}{l}\text { Temozolomide- } \\
\text { Irinotecan }\end{array}$ & Bevacizumab & NA & Death & 2 & $N R$ \\
\hline (23) & NR & MAl & VAC & $\begin{array}{l}\text { Ridaforolimus } \\
\text { Sunitinib }\end{array}$ & NA & NA & NA & NR & 4 & 38 \\
\hline (23) & NR & IVADo Bevacizumab & Navelbine-cyclophosphamide & $\begin{array}{l}\text { Dalotuzumab } \\
\text { Sunitinib }\end{array}$ & NA & NA & NA & NR & 3 & NR \\
\hline (23) & NR & Adriamycin-ifosfamide-etoposide & Cyclophosphamide & Trabectedin & Sunitinib & NA & NA & NR & 2 & 19 \\
\hline (23) & NR & MAl & VAC & Sunitinib & NA & NA & NA & NR & 2 & NR \\
\hline (23) & NR & LV5Fu-Ciplatine & HIPEC-FOLFIRI & FOLFIRI & Holoxan-etoposide & $\mathrm{AC}$ & Sorafenib & PD & 3.5 & $N R$ \\
\hline (23) & NR & MAl & Gemcitabine-docetaxel & Al & Cisplatin-irinotecan & Trabectedin & Sorafenib & PD & 4 & NR \\
\hline (116) & $38 / \mathrm{M}$ & Chemotherapy (NR) & Anlotinib & NA & NA & NA & NA & NR & 4 & NR \\
\hline Hospital & $46 / M$ & MAID & GD & Apatinib & NA & NA & NA & PR & $>14$ & $>21$ \\
\hline Hospital & 28/M & VAl, Anlotinib & NA & NA & NA & NA & NA & SD & $>6$ & NO \\
\hline
\end{tabular}

DSRCT, intra-abdominal desmoplastic small round cell tumor; $M$, male; $F$, female; $T$, target therapy; $P R$, partial response; OS, overall survival; PFS, progression-free survival; ASCT, autologous stem cell transplantation; NR, not reported; $N A$, not available; PCB, carboplatin-paclitaxel; MAID, mesna-adriblastine-ifosfamide-dacarbazine; ASCT, autologous stem cell transplantation; HIPEC, hyperthermic intraperitoneal chemotherapy; FOLFIRI, 5 FU-oxaliplatin-irinotecan; MAl, mesnaadriblastine-ifosfamide; VAl, vincristine-actinomycin-ifosfamide; VAC, vincristine-actinomycin D-cyclophosphamide; IVADo, ifosfamide-vincristine-actinomycin D-doxorubicin; GD, gemcitabine plus docetaxel; AC, adriamycincyclophosphamide; Al, adriamycin-holoxan.

The bold values represent the targeted therapy during the treatment process. 
TABLE 6 | Clinical trials of DSRCT patients.

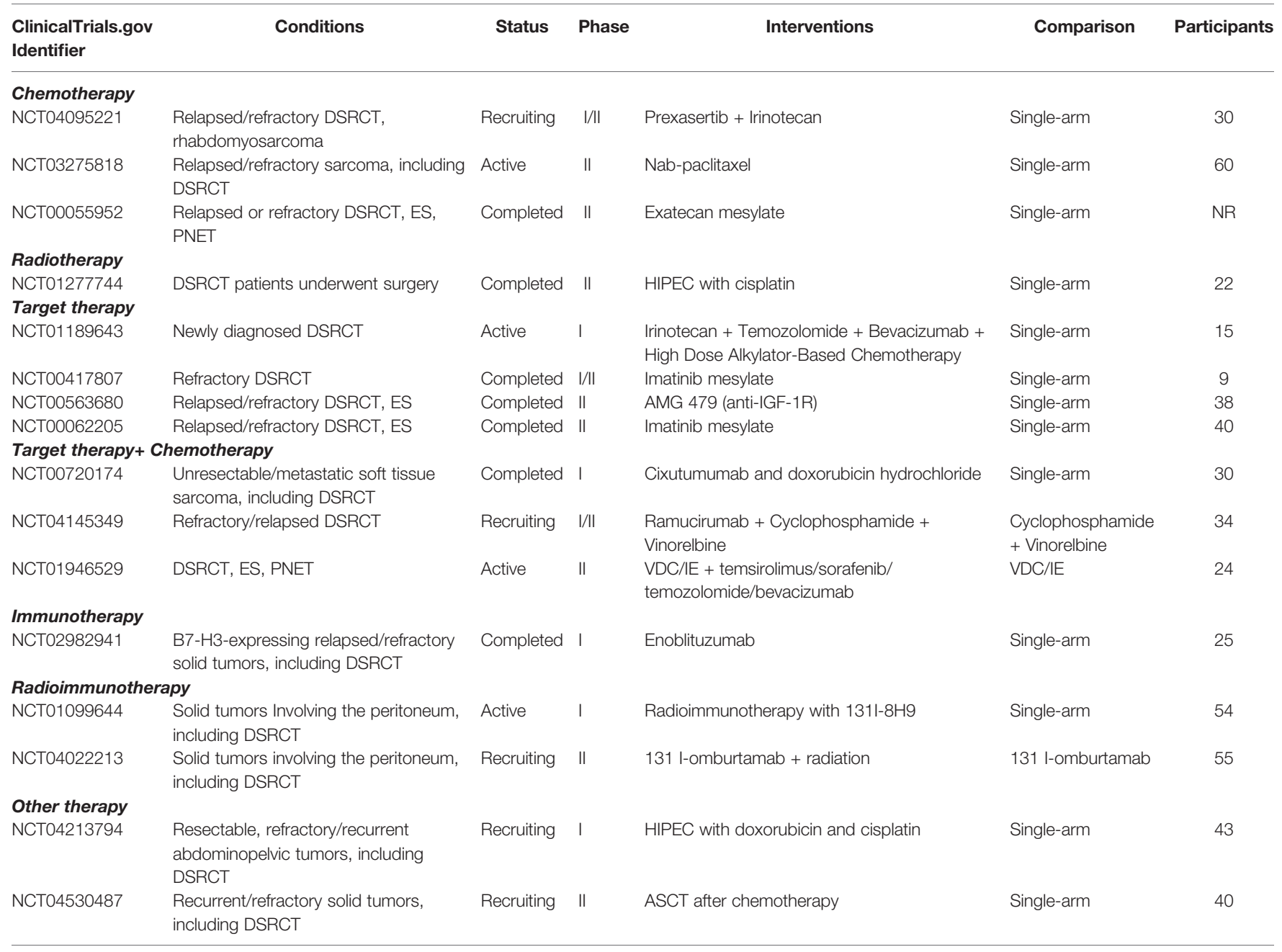

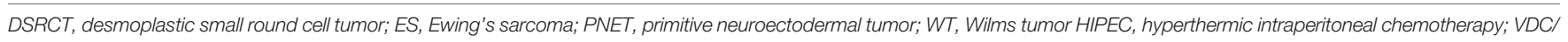
IE, vincristine/doxorubicin/cyclophosphamide alternating with etoposide/ifosfamide, CHPP, continuous hyperthermic peritoneal perfusion; ASCT, allogeneic stem cell transplantation.

\subsubsection{Apatinib}

Apatinib, a novel multitargeted TKI, inhibits the expression of VEGFR-2, RET, c-Kit, and c-Src tyrosine kinases, selectively targeting VEGFR-2 (125). Apatinib is used for treating several tumor types, including gastric neoplasm (126), non-small cell lung cancer (NSCLC) (127), and colorectal cancer (CRC) (128). A case report showed that the tumor-related symptoms of IDSRCT patients were reduced quickly after the initiation of apatinib treatment (76). In another case report, one patient with IDSRCT received systemic chemotherapy (cyclophosphamide, epirubicin, and vincristine) plus apatinib and achieved PR after two cycles of treatment (115). Apatinib may be an alternative strategy for patients with IDSRCT. In a previous study, we presented the case of a 46-year-old man with metastatic IDSRCT admitted to our hospital. Although he had failed the first-line (MAID: mesna, doxorubicin, ifosfamide, and dacarbazine) and second-line chemotherapies (GD: gemcitabine plus docetaxel), he showed positive response to apatinib and quickly reached $\mathrm{PR}$ and achieved more than 14 months of PFS. This patient needed to reduce the dose of apatinib because of grade 3 hypertension and grade 2 digestive tract reaction. These adverse reactions resolved rapidly after dose reduction and usage of hypotensors.

\subsubsection{Anlotinib}

Anlotinib mainly targets VEGFRs $1-3$, PDGFR- $\alpha$ and $-\beta$, fibroblast growth factor receptors (FGFRs) 1-4, EGFR, c-Kit, Met, and stem cell factor receptors $(104,116)$. Anlotinib plays a crucial role in the treatment of NSCLC and thyroid cancer (129). A case report showed that one IDSRCT patient who progressed after resection and chemotherapy (ifosfamide and liposomal doxorubicin) received anlotinib as the second-line therapy, which reduced invasive lymph node size with a PFS of 4 months. Only fatigue (grade $=1$ ) and high triglyceride levels (grade $=1$ ) were observed as side effects (104). In a previous study, we presented the case of a 28 -year-old man admitted to our hospital with multiple metastatic and unresectable IDSRCT lesions. He received anlotinib plus chemotherapy (VAI) as the first-line treatment and achieved an SD of over 6 months. 


\subsubsection{Imatinib}

Imatinib mesylate has been recommended as a treatment for GISTs and chronic myeloid leukemia (130). Notably, this agent also targets other tyrosine kinase receptors, such as PDGF-R and c-KIT (111). PDGF-A and PDGFR- $\beta$ are related to tumor cell growth and proliferation (38) and are overexpressed in DSRCT (119). However, the efficacy of imatinib for IDSRCT has been found to be limited. Eight patients who were refractory to conventional treatment were administered imatinib, and only one patient achieved SD, while seven patients progressed rapidly 3 months after the initiation of imatinib. The toxicities were tolerated, and no severe adverse events were observed (111). Similarly, a phase II study suggested that imatinib was not associated with clinical benefits in pediatric patients with refractory DSRCT (131).

\subsubsection{Monoclonal Antibody Targeting VEGF}

Bevacizumab is a monoclonal antibody that targets VEGF-A. It has been recommended for the treatment of metastatic CRC, advanced NSCLC, advanced cervical cancer, and metastatic RCC (132). A previous study has found that VEGFR-2 and VEGFA are overexpressed in DSRCT cell lines and xenograft models (31). One IDSRCT patient who underwent prior partial resection received bevacizumab and achieved an OS of 34 months (68). Notably, bevacizumab in combination with WART can be used to eradicate residual disease after surgery because it increases the sensitivity of the tumor nodules to radiotherapy (106). An ongoing clinical trial (NCT01189643) is exploring the combination of irinotecan, temozolomide, and bevacizumab in combination with standard P6 regimen for treatment of newly diagnosed patients with DSRCT. Similarly, ramicirumab, an anti-VEGF-2 monoclonal antibody, in combination with chemotherapy, is being assessed in a phase II clinical trial on DSRCT (Table 4; NCT04145349).

\subsubsection{IGF1R Inhibitor}

IGF1R inhibitors can inhibit the proliferation of tumor cells by blocking the binding between IGF1R and IGF-1 and 2 (133). In addition, these inhibitors exert anti-angiogenic effects by targeting VEGF (134). Common IGF1R inhibitors include ganitumab and cixutumumab. IGF1R inhibitors are used for treating ES (135). In a Phase II study, 25\% of clinical benefit (DCR $\geq 6$ months) was achieved in DSRCT patients treated with ganitumab. This study suggested that ganitumab could prolong the survival of DSRCT patients with a median PFS of 19.0 months. Notably, five patients had to undergo dose reductions due to thrombocytopenia (grade $=3$ ) caused by ganitumab. Other grade 3 toxicities, including hyperglycemia, leukopenia, neutropenia, and grade 4 thrombocytopenia, were also reported (112). In another study, SD was observed in two-thirds of pretreated patients who received cixutumumab in combination with temsirolimus (an mTOR inhibitor) (113).

\subsection{9. mTOR Inhibitor}

The PI3K/Akt/mTOR pathway is constitutively activated in DSRCT progression, mainly through mTORC-2 expression
(136), and it is related to cancer cell growth and survival in sarcoma (137). One IDSRCT patient, who resisted chemotherapy and anti-androgen therapy, maintained an SD of 10 months when treated with temsirolimus (114). Furthermore, mTOR inhibitor plus pazopanib led to an SD of 11 months in one IDSRCT patient who progressed after treatment with pazopanib alone (59). Nevertheless, mTOR inhibitor plus IGF1R inhibitor showed limited efficacy in DSRCT treatment (138).

\subsubsection{PARP Inhibitors}

The DDR network may be a potential target for DSRCT due to the recent discovery that $27 \%$ of mutated genes of DSRCT are related to DDR (35). Poly (ADP-ribose) polymerase 1 (PARP1) is a key enzyme for base excision repair of single-strand DNA breaks, participating the recruitment of DNA repair proteins (139). PARP inhibitor has been reported to be effective in sarcoma with deficiency in DDR (38). Anke E. M. van Erp and coworkers discovered that PARP1 expression was observed in $100 \%$ of clinically derived DSRCT tumor tissues (100). They also found that DSRCT cells have a high sensitivity profile to the PARP inhibitor olaparib, and the combination of olaparib with temozolomide (an alkylating agent) in JN-DSRCT-1 cells results in synergistic effects, inducing cell cycle arrest followed by cell apoptosis, consequently leading to tumor reduction in vitro and in vivo.

IDSRCT patients who progress or relapse after first- and second-line treatment can first receive anti-VEGF monoclonal antibodies, like bevacizumab or TKI, that act on multiple pathways simultaneously (e.g., c-Kit, PDGFR- $\alpha$ and $-\beta$, and VEGFR-1, 2 , and 3, Flt3, RET), including pazopanib, sunitinib, anlotinib, and apatinib. Among them, imatinib and sorafenib caused no benefit, which should not be considered in IDSRCT patients. Subsequent lines of management include IGF1R inhibitor or mTOR inhibitor. Notably, the effect of PARP inhibitor needs to be further verified in clinical studies. The existing preclinical and clinical data suggest some effect of targeted therapy in IDSRCT patients. However, the observed role predominantly is tumor stabilization rather than disease regression. Those potential targets are worthy of further exploration $(23,53,68,76,100,110-114)$.

\subsection{Immunotherapy}

Although immunotherapy has shown an unprecedented response in multiple tumor types, there is no clinical evidence of its efficacy in IDSRCT. Some potential targets for immunotherapy have been detected in IDSRCT. CD276, now called B7H3, and GD2 are expressed in $96 \%$ and $70 \%$ of DSRCT patients, respectively (140). $\mathrm{B} 7 \mathrm{H} 3$ can lead to tumor cell immune evasion by inhibiting the effect of T cells, allowing tumor growth and metastasis (33). A phase I study indicated that intraperitoneal radioimmunotherapy with 131I-omburtamab (an anti-B7H3 monoclonal antibody) is well tolerated in patients with DSRCT (141). In addition, antiB7H3 CAR-T cell immunotherapy has been evaluated in a phase I study for recurrent/refractory solid tumors, including DSRCT (Table 4; NCT04483778; NCT02982941). A clinical trial is studying the efficacy of intraperitoneal radioimmunotherapy 
with 131I-8H9 for patients with DSRCT (NCT01099644). The function of GD2 in IDSRCT has not been adequately identified. However, some studies have indicated that GD2 might increase the adhesion between extracellular matrix proteins and tumor cells and contribute to the metastasis of the neoplasm (33). Notably, GD3, an upstream molecule in the biosynthesis of GD2, has also been found in $70.0 \%$ of DSRCT patients. We speculate that GD3 may be a potential target of immunotherapy in IDSRCT patients (142). Immune checkpoint inhibitors targeting PD-1 and CTLA-4 have been demonstrated to prolong survival in several tumors, including NSCLC, RCC, and melanoma (143), but its clinical effect in IDSRCT remains unknown. Pembrolizumab, an anti-PD-1 agent, is now being tested in patients with rare sarcoma (including 6 patients with DSRCT) in a phase 2 clinical trial (NCT03012620).

\subsection{Androgen Blockade Agent}

Bulbul et al. reported higher expression of androgen receptor in DSRCT patients than in those with ES (144). Hence, androgen blockade agents were tested in IDSRCT patients, but its efficacy remains controversial. In a case report analyzing six patients treated with combined androgen blockade, $50 \%$ of the patients showed a positive response to the therapy (132), while in one patient, the tumor progressed after 2 months of treatment (114).

\subsection{Autologous Stem Cell Transplant}

ASCT has been performed in IDSRCT patients (145). In a case report, a complete response (CR) was seen in IDSRCT patients after resection, chemotherapy (VAC+VAP), and ASCT (146). Another study also found that ASCT could significantly improve OS in DSRCT patients who were in remission (147). Moreover, a retrospective study reported improved disease-free survival and OS in ASCT-treated DSRCT patients with residual tumors (148). Owing to the small sample size of the abovementioned studies, the true effectiveness of ASCT needs further validation in the future.

\section{PALLIATIVE CARE AND COMPLICATIONS MANAGEMENT}

Advanced IDSRCT patients with extensive systemic metastases who cannot tolerate surgery or systemic chemotherapy may consider targeted therapy with mild adverse reactions, including TKI inhibitors, mTOR inhibitors, or bevacizumab $(53,59,68,121)$. Nutritional care is essential for patients with advanced tumors. Pharmacological agents and pharmaconutrients have limited effects in patients with advanced cancer. If possible, patients with advanced tumor should engage in regular physical activity and adopt a prudent diet (149). For patients with tumor mass-associated compression symptoms, like intestinal obstruction and ureteral obstruction, palliative surgery can be considered, but the benefits and risks of palliative surgery must be balanced with special consideration in patients with advanced IDSRCT.

\section{PROGNOSIS AND FOLLOW-UP}

The prognosis of IDSRCT is poor. Patients with IDSRCT had a dismal survival with 3 - and 5-year survival rates from $44 \%$ to $15 \%-25 \%$ and a median OS of 1725 months $(70,75)$. Patients with hepatic/portal metastasis (150), resistance to neoadjuvant chemotherapy (27), and CD99 staining positive expression (100) have worse prognosis. Furthermore, local solitary lesions, no metastases, complete CRS, and adjuvant chemotherapy were independent risk factors for OS of IDSRCT (151). Some studies argued that some factors, such as sex, age, postoperative complications, lymph node metastases, the presence of extraabdominal lesions at initial presentation, and tumor size (1, 29, 102), have no significant effect on the survival of IDSRCT. Despite the implementation of multimodal therapy, most IDSRCT patients experience quick relapses with a median PFS of 10-14 months $(27,75)$. Therefore, close follow-up is necessary after completion of treatment. If possible, PET-CT scan every 3 to 6 months is required, which can detect the change of metabolic activity prior to macroscopic neoplasm growth (90).

\section{FUTURE PERSPECTIVES}

CRS combined with VDC/IE chemotherapy regimen and WAPRT are regarded as the standard treatments for IDSRCT. Other therapies, such as molecularly targeted treatments, ASCT, and androgen blockade agents, can be considered when tumor progresses or relapses after standard therapy. Despite multimodal treatments, IDSRCT still has a dismal clinical outcome. The targeted agents for optimal effectiveness for IDSRCT remain unclear. Further research should be directed at exploring the potential effect of various targeted therapies in these patients with IDSRCT. Several potential targets like the DDR or MErT/EMT are waiting further exploration. Furthermore, immunotherapy as a possible therapeutic choice has limited extent effect in preclinical studies, which should be further verified in clinical conditions in the future.

\section{CONCLUSION}

IDSRCT refers to a rare and aggressive soft tissue malignancy that predominantly occurs in a young male population. It is often diagnosed with extensive peritoneal metastasis and has a dismal prognosis. Immunohistochemical analyses of IDSRCT are characterized by co-expression of epithelial, neuronal, and mesenchymal differentiation markers. FISH or reverse transcription polymerase chain reaction detecting EWS-WT1 fusion can be performed to assist in molecular confirmation. Multimodal treatments, including surgery, chemotherapy, and radiotherapy, in patients with IDSRCT have achieved improved outcome. Currently, targeted therapy and immunotherapy have expanded the treatment options for IDSRCT patients and are 
associated with improved survival rates in preclinical or clinical studies. Hepatic/portal metastasis and effect of neoadjuvant chemotherapy, number of lesions, and surgery types are associated with prognosis of IDSRCT. Due to the rarity and poor prognosis of this neoplasm, further studies are required to propose effective regimens for IDSRCT patients.

\section{DATA AVAILABILITY STATEMENT}

The original contributions presented in the study are included in the article/supplementary material. Further inquiries can be directed to the corresponding author.

\section{REFERENCES}

1. Honoré C, Atallah V, Mir O, Orbach D, Ferron G, LePéchoux C, et al. Abdominal Desmoplastic Small Round Cell Tumor Without Extraperitoneal Metastases: Is There a Benefit for HIPEC After Macroscopically Complete Cytoreductive Surgery? PloS One (2017) 12(2): e0171639. doi: 10.1371/journal.pone.0171639

2. Ertoy Baydar D, Armutlu A, Aydin O, Dagdemir A, Yakupoglu YK. Desmoplastic Small Round Cell Tumor of the Kidney: A Case Report. Diagn Pathol (2020) 15(1):95. doi: 10.1186/s13000-020-01015-w

3. Pickhardt PJ, Fisher AJ, Balfe DM, Dehner LP, Huettner PC. Desmoplastic Small Round Cell Tumor of the Abdomen: Radiologic-Histopathologic Correlation. Radiology (1999) 210(3):633-8. doi: 10.1148/radiology.210.3. r99mr42633

4. Saleh D, Al-Maghrabi S, Al-Maghrabi H, Al-Maghrabi J. Desmoplastic Small Round Cell Tumor of Pancreatic Origin in a Young Child: A Case Report and Review of Literature. Am J Case Rep (2020) 21:e922762. doi: 10.12659/AJCR.922762

5. Huang J, Sha L, Zhang H, Tang X, Zhang X. Desmoplastic Small Round Cell Tumor in Transverse Colon: Report of a Rare Case. Int Surg (2015) 100 (5):809-13. doi: 10.9738/INTSURG-D-14-00134.1

6. Zhang GM, Zhu Y, Gan HL, Ye DW. Testicular Desmoplastic Small Round Cell Tumor: A Case Report and Review of Literature. World J Surg Oncol (2014) 12:227. doi: 10.1186/1477-7819-12-227

7. Vujić G, Mikuš M, Matak L, Bonevski A, Babić I, Planinić P, et al. Desmoplastic Small Round Cell Tumor of the Ovary: A Case Report With a New Modality of Treatment and Review of the Literature. Rev Bras Ginecol Obstet (2020) 42(5):297-302. doi: 10.1055/s-0040-1710350

8. Jin D, Chen M, Wang B, Gou Y. Mediastinal Desmoplastic Small Round Cell Tumor. Med (Baltimore) (2020) 99(44):e22921. doi: 10.1097/ MD.0000000000022921

9. Ouarssani A, Atoini F, Ait Lhou F, Rguibi Idrissi M. Desmoplastic Small Round Cell Tumor of the Pleura. Thorac Cancer (2011) 2(3):117-9. doi: 10.1111/j.1759-7714.2011.00046.x

10. Syed S, Haque AK, Hawkins HK, Sorensen PH, Cowan DF. Desmoplastic Small Round Cell Tumor of the Lung. Arch Pathol Lab Med (2002) 126 (10):1226-8. doi: 10.5858/2002-126-1226-DSRCTO

11. Cai Z, Zhang L, Karni RJ, Saluja K, Liu J, Zhu H. Desmoplastic Small Round Cell Tumor of Parotid Gland: A Rare Entity With Diagnostic Challenge. Int J Surg Pathol (2020) 28(7):782-6. doi: 10.1177/1066896920913109

12. Pang B, Leong CC, Salto-Tellez M, Petersson F. Desmoplastic Small Round Cell Tumor of Major Salivary Glands: Report of 1 Case and a Review of the Literature. Appl Immunohistochem Mol Morphol (2011) 19(1):70-5. doi: 10.1097/PAI.0b013e3181eec73c

13. Xu J, Yao M, Yang X, Liu T, Wang S, Ma D, et al. Desmoplastic Small Round Cell Tumor of the Middle Ear: A Case Report. Med (Baltimore) (2018) 97 (17):e0494. doi: 10.1097/MD.0000000000010494

14. Tao Y, Shi L, Ge L, Yuan T, Shi L. Sinonasal Desmoplastic Small Round Cell Tumor: A Case Report and Review of the Literature. BMC Cancer (2019) 19 (1):868. doi: 10.1186/s12885-019-6076-4

\section{AUTHOR CONTRIBUTIONS}

GW reviewed the literature, and wrote the manuscript. XS wrote and revised the manuscript. YZ rechecked the manuscript. XL and $\mathrm{XC}$ assisted in drawing. MQ designed and revised the manuscript.

\section{FUNDING}

This work was supported by the research and development important project of the Science and Technology Bureau in Sichuan (2018SZ0188).

15. He XR, Liu Z, Wei J, Li WJ, Liu T. Primary Desmoplastic Small Round Cell Tumor in the Left Orbit: A Case Report and Literature Review. Int Ophthalmol (2019) 39(2):471-5. doi: 10.1007/s10792-018-0829-y

16. Thondam SK, du Plessis D, Cuthbertson DJ, Das KS, Javadpour M, MacFarlane IA, et al. Intracranial Desmoplastic Small Round Cell Tumor Presenting as a Suprasellar Mass. J Neurosurg (2015) 122(4):773-7. doi: 10.3171/2014.10.JNS132490

17. Asadbeigi SN, Zhang L, Linos K. Subcutaneous Desmoplastic Small RoundCell Tumor: An Unusual Primary Location Expanding the Differential of Superficial Round-Cell Tumors. J Cutan Pathol (2020) 47(8):768-75. doi: 10.1111/cup.13703

18. Yoshida A, Edgar MA, Garcia J, Meyers PA, Morris CD, Panicek DM. Primary Desmoplastic Small Round Cell Tumor of the Femur. Skeletal Radiol (2008) 37(9):857-62. doi: 10.1007/s00256-008-0501-0

19. Adsay V, Cheng J, Athanasian E, Gerald W, Rosai J. Primary Desmoplastic Small Cell Tumor of Soft Tissues and Bone of the Hand. Am J Surg Pathol (1999) 23(11):1408-13. doi: 10.1097/00000478-199911000-00012

20. Thway K, Noujaim J, Zaidi S, Miah AB, Benson C, Messiou C, et al. Desmoplastic Small Round Cell Tumor: Pathology, Genetics, and Potential Therapeutic Strategies. Int J Surg Pathol (2016) 24(8):672-84. doi: $10.1177 / 1066896916668637$

21. Gerald WL, Haber DA. The EWS-WT1 Gene Fusion in Desmoplastic Small Round Cell Tumor. Semin Cancer Biol (2005) 15(3):197-205. doi: 10.1016/ j.semcancer.2005.01.005

22. Gedminas JM, Chasse MH, McBrairty M, Beddows I, Kitchen-Goosen SM, Grohar PJ. Desmoplastic Small Round Cell Tumor is Dependent on the EWS-WT1 Transcription Factor. Oncogenesis (2020) 9(4):41. doi: 10.1038/ s41389-020-0224-1

23. Bétrian S, Bergeron C, Blay JY, Bompas E, Cassier PA, Chevallier L, et al. Antiangiogenic Effects in Patients With Progressive Desmoplastic Small Round Cell Tumor: Data From the French National Registry Dedicated to the Use of Off-Labeled Targeted Therapy in Sarcoma (OUTC's). Clin Sarcoma Res (2017) 7:10. doi: 10.1186/s13569-017-0076-4

24. Li G, Wang HT, Gao Y, Cui XJ, Zhang GZ. Primary Abdominopelvic Desmoplastic Small Round Cell Tumor: CT and Correlated Clinicopathologic Features. Eur Rev Med Pharmacol Sci (2014) 18(18):2670-7.

25. Lal DR, Su WT, Wolden SL, Loh KC, Modak S, La Quaglia MP. Results of Multimodal Treatment for Desmoplastic Small Round Cell Tumors. J Pediatr Surg (2005) 40(1):251-5. doi: 10.1016/j.jpedsurg.2004.09.046

26. Lettieri CK, Garcia-Filion P, Hingorani P. Incidence and Outcomes of Desmoplastic Small Round Cell Tumor: Results From the Surveillance, Epidemiology, and End Results Database. J Cancer Epidemiol (2014) 2014:680126. doi: 10.1155/2014/680126

27. Subbiah V, Lamhamedi-Cherradi SE, Cuglievan B, Menegaz BA, Camacho P, Huh W, et al. Multimodality Treatment of Desmoplastic Small Round Cell Tumor: Chemotherapy and Complete Cytoreductive Surgery Improve Patient Survival. Clin Cancer Res (2018) 24(19):4865-73. doi: 10.1158/10780432.CCR-18-0202

28. Honoré C, Delhorme JB, Nassif E, Faron M, Ferron G, Bompas E, et al. Can We Cure Patients With Abdominal Desmoplastic Small Round Cell Tumor? 
Results of a Retrospective Multicentric Study on 100 Patients. Surg Oncol (2019) 29:107-12. doi: 10.1016/j.suronc.2019.04.002

29. Wong HH, Hatcher HM, Benson C, Al-Muderis O, Horan G, Fisher C, et al. Desmoplastic Small Round Cell Tumour: Characteristics and Prognostic Factors of 41 Patients and Review of the Literature. Clin Sarcoma Res (2013) 3(1):14. doi: 10.1186/2045-3329-3-14

30. Livaditi E, Mavridis G, Soutis M, Papandreou E, Moschovi M, Papadakis V, et al. Diffuse Intraabdominal Desmoplastic Small Round Cell Tumor: A TenYear Experience. Eur J Pediatr Surg (2006) 16(6):423-7. doi: 10.1055/s-2006924736

31. Bulbul A, Fahy BN, Xiu J, Rashad S, Mustafa A, Husain H, et al. Desmoplastic Small Round Blue Cell Tumor: A Review of Treatment and Potential Therapeutic Genomic Alterations. Sarcoma (2017) 2017:1278268. doi: $10.1155 / 2017 / 1278268$

32. Lee SB, Kolquist KA, Nichols K, Englert C, Maheswaran S, Ladanyi M, et al. The EWS-WT1 Translocation Product Induces PDGFA in Desmoplastic Small Round-Cell Tumour. Nat Genet (1997) 17(3):309-13. doi: 10.1038/ ng1197-309

33. Loktev A, Shipley JM. Desmoplastic Small Round Cell Tumor (DSRCT): Emerging Therapeutic Targets and Future Directions for Potential Therapies. Expert Opin Ther Targets (2020) 24(4):281-5. doi: 10.1080/ 14728222.2020 .1738392

34. Ito E, Honma R, Imai J, Azuma S, Kanno T, Mori S, et al. A TetraspaninFamily Protein, T-Cell Acute Lymphoblastic Leukemia-Associated Antigen 1, is Induced by the Ewing's Sarcoma-Wilms' Tumor 1 Fusion Protein of Desmoplastic Small Round-Cell Tumor. Am J Pathol (2003) 163(6):2165-72. doi: 10.1016/S0002-9440(10)63573-0

35. Devecchi A, De Cecco L, Dugo M, Penso D, Dagrada G, Brich S, et al. The Genomics of Desmoplastic Small Round Cell Tumor Reveals the Deregulation of Genes Related to DNA Damage Response, EpithelialMesenchymal Transition, and Immune Response. Cancer Commun (Lond) (2018) 38(1):70. doi: 10.1186/s40880-018-0339-3

36. Yang J, Du X, Wang G, Sun Y, Chen K, Zhu X, et al. Mesenchymal to Epithelial Transition in Sarcomas. Eur J Cancer (2014) 50(3):593-601. doi: 10.1016/j.ejca.2013.11.006

37. Jiang Y, Subbiah V, Janku F, Ludwig JA, Naing A, Benjamin RS, et al. Novel Secondary Somatic Mutations in Ewing's Sarcoma and Desmoplastic Small Round Cell Tumors. PloS One (2014) 9(8):e93676. doi: 10.1371/ journal.pone.0093676

38. Bexelius TS, Wasti A, Chisholm JC. Mini-Review on Targeted Treatment of Desmoplastic Small Round Cell Tumor. Front Oncol (2020) 10:518. doi: 10.3389/fonc. 2020.00518

39. Thomas R, Rajeswaran G, Thway K, Benson C, Shahabuddin K, Moskovic E. Desmoplastic Small Round Cell Tumour: The Radiological, Pathological and Clinical Features. Insights Imaging (2013) 4(1):111-8. doi: 10.1007/s13244012-0212-x

40. Morani AC, Bathala TK, Surabhi VR, Yedururi S, Jensen CT, Huh WW, et al. Desmoplastic Small Round Cell Tumor: Imaging Pattern of Disease at Presentation. AJR Am J Roentgenol (2019) 212(3):W45-w54. doi: 10.2214/ AJR.18.20179

41. Nacef K, Chaouch MA, Bouriga R, Khalifa MB, Chaouch A, Ghannouchi M, et al. A Case Report of Abdominal Desmoplastic Small Round Cell Tumor in a Young Tunisian Woman. J Gastrointest Cancer (2019) 50(3):568-71. doi: 10.1007/s12029-017-0048-1

42. Ambar NBD, de Seixas Alves MT, Lederman HM, Abib S, Duarte AAB, Caran EM. Irinotecan and Vincristine for the Treatment of Refractory Desmoplastic Small Round Cell Tumor in a Developing Country: A Case Report. J Med Case Rep (2019) 13(1):77. doi: 10.1186/s13256-019-1985-z

43. Altal OF, Aleshawi AJ, Tashtush NA, Alhowary A. A 23-Year-Old Joradanian Woman With a Desmoplastic Small Round Cell Tumor Involving the Ovary. Am J Case Rep (2019) 20:1675-8. doi: 10.12659/ AJCR. 919488

44. Ferreira EN, Barros BD, de Souza JE, Almeida RV, Torrezan GT, Garcia S, et al. A Genomic Case Study of Desmoplastic Small Round Cell Tumor: Comprehensive Analysis Reveals Insights Into Potential Therapeutic Targets and Development of a Monitoring Tool for a Rare and Aggressive Disease. Hum Genomics (2016) 10(1):36. doi: 10.1186/ s40246-016-0092-0
45. López-González A, Cantos B, Tejerina E, Provencio M. Activity of Trabectidin in Desmoplastic Small Round Cell Tumor. Med Oncol (2011) 28:S644-6. doi: 10.1007/s12032-010-9687-9

46. Shen CJ, Loeb DM, Terezakis SA. Desmoplastic Small Round Cell Tumor: Postoperative Retroperitoneal Mass. Radiol Case Rep (2016) 11(3):248-50. doi: 10.1016/j.radcr.2016.05.007

47. Li X, Yu J, Fang S, Xing X, Zhao J. Desmoplastic Small Round Cell Tumor: A Case Report and Review of the Literature. World J Surg Oncol (2014) 12:9. doi: 10.1186/1477-7819-12-9

48. Reisner D, Brahee D, Patel S, Hartman M. A Case of Desmoplastic Small Round Cell Tumor. J Radiol Case Rep (2015) 9(8):1-7. doi: 10.3941/ jrcr.v9i8.2526

49. Briseño-Hernández AA, Quezada-López DR, Corona-Cobián LE, Castañeda-Chávez A, Duarte-Ojeda AT, Macías-Amezcua MD. [IntraAbdominal Desmoplastic Small Round Cell Tumour]. Cir Cir (2015) 83 (3):243-8. doi: 10.1016/j.circir.2015.05.009

50. Kandhari C, Muddebihal U, Udupa V, Chandra S. Desmoplastic Small Round Cell Tumor (DSRCT): An Unusual Intra-Abdominal Tumor. Indian J Surg (2015) 77(1):67-9. doi: 10.1007/s12262-013-0990-5

51. Nathan JD, Gingalewski C, Salem RR. Intra-Abdominal Desmoplastic Small Round Cell Tumor. Yale J Biol Med (2001) 74(1):13-20.

52. Ferrari A, Grosso F, Stacchiotti S, Meazza C, Zaffignani E, Marchianò A, et al. Response to Vinorelbine and Low-Dose Cyclophosphamide Chemotherapy in Two Patients With Desmoplastic Small Round Cell Tumor. Pediatr Blood Cancer (2007) 49(6):864-6. doi: 10.1002/pbc.20682

53. Italiano A, Kind M, Cioffi A, Maki RG, Bui B. Clinical Activity of Sunitinib in Patients With Advanced Desmoplastic Round Cell Tumor: A Case Series. Target Oncol (2013) 8(3):211-3. doi: 10.1007/s11523-012-0251-8

54. Frezza AM, Whelan JS, Dileo P. Trabectedin for Desmoplastic Small Round Cell Tumours: A Possible Treatment Option? Clin Sarcoma Res (2014) 4:3. doi: 10.1186/2045-3329-4-3

55. Azami A, Takano Y, Honda M, Todate Y, Tada T, Waragai M, et al. [A Case of an Abdominal Desmoplastic Small Round Cell Tumor With Metastasis in the Medulla Oblongata]. Gan To Kagaku Ryoho (2016) 43(11):1409-12.

56. Takahira K, Ohi S, Fujii N, Matsuura Y, Sano M, Hanai H, et al. IntraAbdominal Desmoplastic Small Round Cell Tumor (IDSRT). J Gastroenterol (2000) 35(9):712-6. doi: 10.1007/s005350070052

57. Wakahashi S, Sudo T, Ichida K, Sugita S, Hasegawa T, Nagao S, et al. Diagnosis of Desmoplastic Small-Round-Cell Tumor by Cytogenetic Analysis: A Case Report. Clin Case Rep (2016) 4(5):520-3. doi: 10.1002/ccr3.558

58. Hirano G, Irie M, Nakashima $Y$, Shakado S, Sohda T, Tanaka T, et al. Desmoplastic Small Round Cell Tumors in a Young Man. Intern Med (2013) 52(17):1909-14. doi: 10.2169/internalmedicine.52.0431

59. Katz D, Azraq Y, Eleyan F, Gill S, Peretz T, Merimsky O. Pazolimus: Pazopanib Plus Sirolimus Following Progression on Pazopanib, a Retrospective Case Series Analysis. BMC Cancer (2016) 16:616. doi: 10.1186/s12885-016-2618-1

60. Slomovitz BM, Girotra M, Aledo A, Saqi A, Soslow RA, Spigland NA, et al. Desmoplastic Small Round Cell Tumor With Primary Ovarian Involvement: Case Report and Review. Gynecol Oncol (2000) 79(1):124-8. doi: 10.1006/ gyno.2000.5829

61. Eaton SH, Cendron MA. Primary Desmoplastic Small Round Cell Tumor of the Kidney in a 7-Year-Old Girl. J Pediatr Urol (2006) 2(1):52-4. doi: 10.1016/j.jpurol.2005.05.008

62. Zhang S, Zhang Y, Yu YH, Li J. Complete Response of Giant Desmoplastic Small Round Cell Tumor Treated With Chemoradiotherapy: A Case Report. Oncol Lett (2016) 11(2):1069-72. doi: 10.3892/ol.2015.4024

63. Xie YP, Shen YM. Ovarian Involvement of a Desmoplastic Small Round Cell Tumor of Unknown Primary Origin With Lymph Node and Lung Metastases: A Case Report. Oncol Lett (2016) 11(2):1125-9. doi: 10.3892/ ol.2015.4012

64. Baz W, El-Soueidi R, Nakhl F, Aoun N, Chin N, Dhar M. Desmoplastic Small Round-Cell Tumor: An Adult With Previous Exposure to Agent Orange. Jpn J Clin Oncol (2010) 40(6):593-5. doi: 10.1093/jjco/hyq022

65. Takekawa Y, Ugajin W, Koide H, Nishio S, Yamamoto T, Sawada T. Pathologic, Cytologic and Immunohistochemical Findings of an IntraAbdominal Desmoplastic Small Round Cell Tumor in a 15-Year-Old Male. Pathol Int (2000) 50(5):417-20. doi: 10.1046/j.1440-1827.2000.01051.x 
66. Ujihara M, Ando T, Watanabe O, Asada T, Yamashita K, Ichihara T, et al. Treatment of Intraabdominal Desmoplastic Small Round Cell Tumor With Ifosfamide-Based Chemotherapy. Clin J Gastroenterol (2010) 3(1):25-9. doi: 10.1007/s12328-009-0131-7

67. Kim JW, Park JH, Cho HJ, Kwon JH, Koh Y, Kim SJ, et al. A Case of Desmoplastic Small Round Cell Tumor Diagnosed in a Young Female Patient. Cancer Res Treat (2009) 41(4):233-6. doi: 10.4143/crt.2009.41.4.233

68. de Araújo RA, Araújo BJ. Desmoplastic Small Round Cell Tumor: Report of 2 Cases Treated With Chemotherapy Alone or in Combination With Bevacizumab. Case Rep Oncol (2014) 7(1):102-8. doi: 10.1159/ 000359997

69. Koniari K, Mahera H, Nikolaou M, Chatzis O, Glezakou O, Magiasis V, et al. Intraabdominal Desmoplastic Small Round Cell Tumor: Report of a Case and Literature Review. Int J Surg Case Rep (2011) 2(8):293-6. doi: 10.1016/ j.ijscr.2011.08.013

70. Honoré C, Amroun K, Vilcot L, Mir O, Domont J, Terrier P, et al. Abdominal Desmoplastic Small Round Cell Tumor: Multimodal Treatment Combining Chemotherapy, Surgery, and Radiotherapy is the Best Option. Ann Surg Oncol (2015) 22(4):1073-9. doi: 10.1245/s10434-014-4123-6

71. Tang Y, Song H, Bao Y, Zhi Y. Multimodal Treatment of Abdominal and Pelvic Desmoplastic Small Round Cell Tumor With Relative Good Prognosis. Int J Surg (2015) 16(Pt A):49-54. doi: 10.1016/j.ijsu.2015.02.015

72. Magro G, Broggi G, Zin A, Di Benedetto V, Meli M, Di Cataldo A, et al. Desmoplastic Small Round Cell Tumor With "Pure" Spindle Cell Morphology and Novel EWS-WT1 Fusion Transcript: Expanding the Morphological and Molecular Spectrum of This Rare Entity. Diagnostics (Basel) (2021) 11(3):545. doi: 10.3390/diagnostics11030545

73. Chicago Consensus Working Group.The Chicago Consensus on Peritoneal Surface Malignancies: Management of Desmoplastic Small Round Cell Tumor, Breast, and Gastrointestinal Stromal Tumors. Cancer (2020) 126 (11):2566-70. doi: 10.1002/cncr.32856

74. Kis B, O'Regan KN, Agoston A, Javery O, Jagannathan J, Ramaiya NH. Imaging of Desmoplastic Small Round Cell Tumour in Adults. Br J Radiol (2012) 85(1010):187-92. doi: 10.1259/bjr/57186741

75. Martínez-Trufero J, Cruz Jurado J, Hernández-León CN, Correa R, Asencio JM, Bernabeu D, et al. Uncommon and Peculiar Soft Tissue Sarcomas: Multidisciplinary Review and Practical Recommendations. Spanish Group for Sarcoma Research (GEIS -GROUP). Part II. Cancer Treat Rev (2021) 99:102260. doi: 10.1016/j.ctrv.2021.102260

76. Shi C, Feng Y, Zhang LC, Ding DY, Yan MY, Pan L. Effective Treatment of Apatinib in Desmoplastic Small Round Cell Tumor: A Case Report and Literature Review. BMC Cancer (2018) 18(1):338. doi: 10.1186/s12885-0184135-x

77. Ordi J, de Alava E, Torné A, Mellado B, Pardo-Mindan J, et al. Intraabdominal desmoplastic small round cell tumor with EWS/ERG fusion transcript. Am J Surg Pathol (1998) 22(8):026-32.

78. Shimazaki J, Motohashi G, Nishida K, Tabuchi T, Ubukuta H. Removal of an intra-abdominal desmoplastic small round cell tumor by repetitive debulking surgery: A case report and literature review. Oncol Lett (2014) 7 (5):1464-8.

79. Devaney K. Intra-abdominal desmoplastic small round cell tumor of the peritoneum in a young man. Ultrastruct Pathol (1994) 18(3):389-98.

80. Hendricks A, Boerner K, Germer CT, Wiegering A. Desmoplastic Small Round Cell Tumors: A Review With Focus on Clinical Management and Therapeutic Options. Cancer Treat Rev (2021) 93:102140. doi: 10.1016/ j.ctrv. 2020.102140

81. Ordóñez NG. Desmoplastic Small Round Cell Tumor: II: An Ultrastructural and Immunohistochemical Study With Emphasis on New Immunohistochemical Markers. Am J Surg Pathol (1998) 22(11):1314-27. doi: 10.1097/00000478-199811000-00002

82. Gerald WL, Rosai J, Ladanyi M. Characterization of the Genomic Breakpoint and Chimeric Transcripts in the EWS-WT1 Gene Fusion of Desmoplastic Small Round Cell Tumor. Proc Natl Acad Sci U.S.A. (1995) 92(4):1028-32. doi: $10.1073 /$ pnas.92.4.1028

83. Werner H, Idelman G, Rubinstein M, Pattee P, Nagalla SR, Roberts CTJr. A Novel EWS-WT1 Gene Fusion Product in Desmoplastic Small Round Cell Tumor is a Potent Transactivator of the Insulin-Like Growth Factor-I
Receptor (IGF-IR) Gene. Cancer Lett (2007) 247(1):84-90. doi: 10.1016/ j.canlet.2006.03.027

84. Nakanishi Y, Oinuma T, Sano M, Fuchinoue F, Komatsu K, Seki T, et al. Coexpression of an Unusual Form of the EWS-WT1 Fusion Transcript and Interleukin 2/15 Receptor betamRNA in a Desmoplastic Small Round Cell Tumour. J Clin Pathol (2006) 59(10):1108-10. doi: 10.1136/jcp.2005.026245

85. Murphy AJ, Bishop K, Pereira C, Chilton-MacNeill S, Ho M, Zielenska M, et al. A New Molecular Variant of Desmoplastic Small Round Cell Tumor: Significance of WT1 Immunostaining in This Entity. Hum Pathol (2008) 39 (12):1763-70. doi: 10.1016/j.humpath.2008.04.019

86. Mohamed M, Gonzalez D, Fritchie KJ, Swansbury J, Wren D, Benson C, et al. Desmoplastic Small Round Cell Tumor: Evaluation of Reverse Transcription-Polymerase Chain Reaction and Fluorescence in Situ Hybridization as Ancillary Molecular Diagnostic Techniques. Virchows Arch (2017) 471(5):631-40. doi: 10.1007/s00428-017-2207-y

87. Lae ME, Roche PC, Jin L, Lloyd RV, Nascimento AG. Desmoplastic Small Round Cell Tumor: A Clinicopathologic, Immunohistochemical, and Molecular Study of 32 Tumors. Am J Surg Pathol (2002) 26(7):823-35. doi: 10.1097/00000478-200207000-00001

88. Angarita FA, Hassan S, Cannell AJ, Dickson BC, Gladdy RA, Swallow CJ, et al. Clinical Features and Outcomes of 20 Patients With Abdominopelvic Desmoplastic Small Round Cell Tumor. Eur J Surg Oncol (2017) 43(2):42331. doi: 10.1016/j.ejso.2016.08.017

89. Wang LL, Ji ZH, Gao Y, Chang H, Sun PP, Li Y. Clinicopathological Features of Desmoplastic Small Round Cell Tumors: Clinical Series and Literature Review. World J Surg Oncol (2021) 19(1):193. doi: 10.1186/s12957-02102310-6

90. Ostermeier A, McCarville MB, Navid F, Snyder SE, Shulkin BL. FDG PET/ CT Imaging of Desmoplastic Small Round Cell Tumor: Findings at Staging, During Treatment and at Follow-Up. Pediatr Radiol (2015) 45(9):1308-15. doi: 10.1007/s00247-015-3315-y

91. Magnan H, Abramson SJ, Price AP, Grewal RK, Merchant MS, LaQuaglia MP, et al. Positron Emission Tomography for Response Assessment in Desmoplastic Small Round Cell Tumor. J Pediatr Hematol Oncol (2013) 35 (5):e190-3. doi: 10.1097/MPH.0b013e3182707d4c

92. Zhang WD, Li CX, Liu QY, Hu YY, Cao Y, Huang JH. CT, MRI, and FDGPET/CT Imaging Findings of Abdominopelvic Desmoplastic Small Round Cell Tumors: Correlation With Histopathologic Findings. Eur J Radiol (2011) 80(2):269-73. doi: 10.1016/j.ejrad.2010.06.046

93. Shen XZ, Zhao JG, Wu JJ, Liu F. Clinical and Computed Tomography Features of Adult Abdominopelvic Desmoplastic Small Round Cell Tumor. World J Gastroenterol (2014) 20(17):5157-64. doi: 10.3748/wjg.v20.i17.5157

94. Hayes-Jordan A, Green H, Fitzgerald N, Xiao L, Anderson P. Novel Treatment for Desmoplastic Small Round Cell Tumor: Hyperthermic Intraperitoneal Perfusion. J Pediatr Surg (2010) 45(5):1000-6. doi: 10.1016/j.jpedsurg.2010.02.034

95. Harmon RL, Sugarbaker PH. Prognostic Indicators in Peritoneal Carcinomatosis From Gastrointestinal Cancer. Int Semin Surg Oncol (2005) 2(1):3. doi: 10.1186/1477-7800-2-3

96. Stuart-Buttle CE, Smart CJ, Pritchard S, Martin D, Welch IM. Desmoplastic Small Round Cell Tumour: A Review of Literature and Treatment Options. Surg Oncol (2008) 17(2):107-12. doi: 10.1016/j.suronc.2007.11.005

97. Cho KJ, Ro JY, Choi J, Choi SH, Nam SY, Kim SY. Mesenchymal Neoplasms of the Major Salivary Glands: Clinicopathological Features of 18 Cases. Eur Arch Otorhinolaryngol (2008) 265:S47-56. doi: 10.1007/s00405-007-0488-5

98. Dufresne A, Cassier P, Couraud L, Marec-Bérard P, Meeus P, Alberti L, et al. Desmoplastic Small Round Cell Tumor: Current Management and Recent Findings. Sarcoma (2012) 2012:714986. doi: 10.1155/2012/714986

99. Quaglia MP, Brennan MF. The Clinical Approach to Desmoplastic Small Round Cell Tumor. Surg Oncol (2000) 9(2):77-81. doi: 10.1016/S0960-7404 (00)00024-4

100. Xiang T, Zhang SY, Wang SS, Fei RS, Li H. A Nationwide Analysis of Desmoplastic Small Round Cell Tumor. Med (Baltimore) (2020) 99(30): e21337. doi: 10.1097/MD.0000000000021337

101. Jacquet P, Sugarbaker PH. Clinical Research Methodologies in Diagnosis and Staging of Patients With Peritoneal Carcinomatosis. Cancer Treat Res (1996) 82:359-74. doi: 10.1007/978-1-4613-1247-5_23 
102. Stiles ZE, Murphy AJ, Anghelescu DL, Brown CL, Davidoff AM, Dickson PV, et al. Desmoplastic Small Round Cell Tumor: Long-Term Complications After Cytoreduction and Hyperthermic Intraperitoneal Chemotherapy. Ann Surg Oncol (2020) 27(1):171-8. doi: 10.1245/s10434-019-07339-2

103. Schwarz RE, Gerald WL, Kushner BH, Coit DG, Brennan MF, La Quaglia MP. Desmoplastic Small Round Cell Tumors: Prognostic Indicators and Results of Surgical Management. Ann Surg Oncol (1998) 5(5):416-22. doi: 10.1007/BF02303860

104. Chen HM, Feng G. Use of Anlotinib in Intra-Abdominal Desmoplastic Small Round Cell Tumors: A Case Report and Literature Review. Onco Targets Ther (2019) 12:57-61. doi: 10.2147/OTT.S190333

105. Chang CC, Hsu JT, Tseng JH, Hwang TL, Chen HM, Jan YY. Combined Resection and Multi-Agent Adjuvant Chemotherapy for Desmoplastic Small Round Cell Tumor Arising in the Abdominal Cavity: Report of a Case. World J Gastroenterol (2006) 12(5):800-3. doi: 10.3748/wjg.v12.i5.800

106. Pinnix CC, Fontanilla HP, Hayes-Jordan A, Subbiah V, Bilton SD, Chang EL, et al. Whole Abdominopelvic Intensity-Modulated Radiation Therapy for Desmoplastic Small Round Cell Tumor After Surgery. Int J Radiat Oncol Biol Phys (2012) 83(1):317-26. doi: 10.1016/j.ijrobp.2011.06.1985

107. Herrero AB, Martín-Castellanos C, Marco E, Gago F, Moreno S. Cross-Talk Between Nucleotide Excision and Homologous Recombination DNA Repair Pathways in the Mechanism of Action of Antitumor Trabectedin. Cancer Res (2006) 66(16):8155-62. doi: 10.1158/0008-5472.CAN-06-0179

108. Deneve JL. ASO Author Reflections: Late-Term Toxicity After Cytoreductive Surgery/Hyperthermic Intraperitoneal Chemotherapy for Desmoplastic Small Round Cell Tumor Underscores the Need for Novel Drug Development and Clinical Trial Design. Ann Surg Oncol (2019) 26(Suppl 3):692-3. doi: 10.1245/s10434-019-07712-1

109. Desai NB, Stein NF, LaQuaglia MP, Alektiar KM, Kushner BH, Modak S, et al. Reduced Toxicity With Intensity Modulated Radiation Therapy (IMRT) for Desmoplastic Small Round Cell Tumor (DSRCT): An Update on the Whole Abdominopelvic Radiation Therapy (WAP-RT) Experience. Int J Radiat Oncol Biol Phys (2013) 85(1):e67-72. doi: 10.1016/j.ijrobp. 2012.09.005

110. Frezza AM, Benson C, Judson IR, Litiere S, Marreaud S, Sleijfer S, et al. Pazopanib in Advanced Desmoplastic Small Round Cell Tumours: A MultiInstitutional Experience. Clin Sarcoma Res (2014) 4:7. doi: 10.1186/20453329-4-7

111. De Sanctis R, Bertuzzi A, Bisogno G, Carli M, Ferrari A, Comandone A, et al. Imatinib Mesylate in Desmoplastic Small Round Cell Tumors. Future Oncol (2017) 13(14):1233-7. doi: 10.2217/fon-2016-0305

112. Tap WD, Demetri G, Barnette P, Desai J, Kavan P, Tozer R, et al. Phase II Study of Ganitumab, a Fully Human Anti-Type-1 Insulin-Like Growth Factor Receptor Antibody, in Patients With Metastatic Ewing Family Tumors or Desmoplastic Small Round Cell Tumors. J Clin Oncol (2012) 30(15):1849-56. doi: 10.1200/JCO.2011.37.2359

113. Naing A, LoRusso P, Fu S, Hong DS, Anderson P, Benjamin RS, et al. Insulin Growth Factor-Receptor (IGF-1R) Antibody Cixutumumab Combined With the mTOR Inhibitor Temsirolimus in Patients With Refractory Ewing's Sarcoma Family Tumors. Clin Cancer Res (2012) 18(9):2625-31. doi: 10.1158/1078-0432.CCR-12-0061

114. Thijs AM, van der Graaf WT, van Herpen CM. Temsirolimus for Metastatic Desmoplastic Small Round Cell Tumor. Pediatr Blood Cancer (2010) 55 (7):1431-2. doi: 10.1002/pbc.22755

115. Tian Y, Cheng X, Li Y. Chemotherapy Combined With Apatinib for the Treatment of Desmoplastic Small Round Cell Tumors: A Case Report. J Cancer Res Ther (2020) 16(5):1177-81. doi: 10.4103/jcrt.JCRT_589_20

116. Syed YY. Anlotinib: First Global Approval. Drugs (2018) 78(10):1057-62. doi: $10.1007 / s 40265-018-0939-x$

117. van Geel RM, Beijnen JH, Schellens JH. Concise Drug Review: Pazopanib and Axitinib. Oncologist (2012) 17(8):1081-9. doi: 10.1634/theoncologist.2012-0055

118. Bukowski RM, Yasothan U, Kirkpatrick P. Pazopanib. Nat Rev Drug Discovery (2010) 9(1):17-8. doi: 10.1038/nrd3073

119. Zhang PJ, Goldblum JR, Pawel BR, Pasha TL, Fisher C, Barr FG. PDGF-A, PDGF-Rbeta, TGFbeta3 and Bone Morphogenic Protein-4 in Desmoplastic Small Round Cell Tumors With EWS-WT1 Gene Fusion Product and Their Role in Stromal Desmoplasia: An Immunohistochemical Study. Mod Pathol (2005) 18(3):382-7. doi: 10.1038/modpathol.3800264
120. Magnan HD, Chou T, LaQuaglia MP, Gerald W, Ladanyi M, Merchant MS. Elevated Expression of VEGFR-2 and VEGFA in Desmoplastic Small Round Cell Tumor (DSRCT) and Activity of Bevacizumab and Irinotecan in a Xenograft Model of DSRCT. (2009) 27: (15_suppl):10016. doi: 10.1200/ jco.2009.27.15_suppl.10016

121. Menegaz BA, Cuglievan B, Benson J, Camacho P, Lamhamedi-Cherradi SE, Leung CH, et al. Clinical Activity of Pazopanib in Patients With Advanced Desmoplastic Small Round Cell Tumor. Oncologist (2018) 23(3):360-6. doi: 10.1634/theoncologist.2017-0408

122. Ferrari SM, Centanni M, Virili C, Miccoli M, Ferrari P, Ruffilli I, et al. Sunitinib in the Treatment of Thyroid Cancer. Curr Med Chem (2019) 26 (6):963-72. doi: 10.2174/0929867324666171006165942

123. Bisht S, Feldmann G, Brossart P. Pharmacokinetics and Pharmacodynamics of Sunitinib for the Treatment of Advanced Pancreatic Neuroendocrine Tumors. Expert Opin Drug Metab Toxicol (2013) 9(6):777-88. doi: 10.1517/ 17425255.2013 .791281

124. Hahn O, Stadler W. Sorafenib. Curr Opin Oncol (2006) 18(6):615-21. doi: 10.1097/01.cco.0000245316.82391.52

125. Scott AJ, Messersmith WA, Jimeno A. Apatinib: A Promising Oral Antiangiogenic Agent in the Treatment of Multiple Solid Tumors. Drugs Today (Barc) (2015) 51(4):223-9. doi: 10.1358/dot.2015.51.4.2320599

126. Scott LJ. Apatinib: A Review in Advanced Gastric Cancer and Other Advanced Cancers. Drugs (2018) 78(7):747-58. doi: 10.1007/s40265-0180903-9

127. Xue JM, Astère M, Zhong MX, Lin H, Shen J, Zhu YX. Efficacy and Safety of Apatinib Treatment for Gastric Cancer, Hepatocellular Carcinoma and nonSmall Cell Lung Cancer: A Meta-Analysis. Onco Targets Ther (2018) 11:6119-28. doi: 10.2147/OTT.S172717

128. Yu T, Wu C, Zhu C, He Y, Yang D, Cheng Y, et al. Oral Administration of Liposome-Apatinib and Locally Delivery of Docetaxel/MPEG-PCL by Fibrin Glue Synergistically Improve Therapeutic Effect in Colorectal Cancer. J BioMed Nanotechnol (2018) 14(12):2077-91. doi: 10.1166/jbn.2018.2651

129. Ruan X, Shi X, Dong Q, Yu Y, Hou X, Song X, et al. Antitumor Effects of Anlotinib in Thyroid Cancer. Endocr Relat Cancer (2019) 26(1):153-64. doi: 10.1530/ERC-17-0558

130. Waller CF. Imatinib Mesylate. Recent Results Cancer Res (2018) 212:1-27. doi: 10.1007/978-3-319-91439-8_1

131. Bond M, Bernstein ML, Pappo A, Schultz KR, Krailo M, Blaney SM, et al. A Phase II Study of Imatinib Mesylate in Children With Refractory or Relapsed Solid Tumors: A Children's Oncology Group Study. Pediatr Blood Cancer (2008) 50(2):254-8. doi: 10.1002/pbc.21132

132. Li M, Kroetz DL. Bevacizumab-Induced Hypertension: Clinical Presentation and Molecular Understanding. Pharmacol Ther (2018) 182:152-60. doi: 10.1016/j.pharmthera.2017.08.012

133. Beltran PJ, Mitchell P, Chung YA, Cajulis E, Lu J, Belmontes B, et al. AMG 479, a Fully Human Anti-Insulin-Like Growth Factor Receptor Type I Monoclonal Antibody, Inhibits the Growth and Survival of Pancreatic Carcinoma Cells. Mol Cancer Ther (2009) 8(5):1095-105. doi: 10.1158/ 1535-7163.MCT-08-1171

134. Kurmasheva RT, Dudkin L, Billups C, Debelenko LV, Morton CL, Houghton PJ. The Insulin-Like Growth Factor-1 Receptor-Targeting Antibody, CP751,871 , Suppresses Tumor-Derived VEGF and Synergizes With Rapamycin in Models of Childhood Sarcoma. Cancer Res (2009) 69(19):7662-71. doi: 10.1158/0008-5472.CAN-09-1693

135. Guenther LM, Dharia NV, Ross L, Conway A, Robichaud AL, Catlett JL2nd, et al. A Combination CDK4/6 and IGF1R Inhibitor Strategy for Ewing Sarcoma. Clin Cancer Res (2019) 25(4):1343-57. doi: 10.1158/10780432.CCR-18-0372

136. Subbiah V, Brown RE, Jiang Y, Buryanek J, Hayes-Jordan A, Kurzrock R, et al. Morphoproteomic Profiling of the Mammalian Target of Rapamycin (mTOR) Signaling Pathway in Desmoplastic Small Round Cell Tumor (EWS/WT1), Ewing's Sarcoma (EWS/FLI1) and Wilms' Tumor(WT1). PloS One (2013) 8(7):e68985. doi: 10.1371/journal.pone.0068985

137. Wan X, Helman LJ. The Biology Behind mTOR Inhibition in Sarcoma. Oncologist (2007) 12(8):1007-18. doi: 10.1634/theoncologist.12-8-1007

138. Wagner LM, Fouladi M, Ahmed A, Krailo MD, Weigel B, DuBois SG, et al. Phase II Study of Cixutumumab in Combination With Temsirolimus in Pediatric Patients and Young Adults With Recurrent or Refractory Sarcoma: 
A Report From the Children's Oncology Group. Pediatr Blood Cancer (2015) 62(3):440-4. doi: 10.1002/pbc.25334

139. van Erp AEM, van Houdt L, Hillebrandt-Roeffen MHS, van Bree N, Flucke UE, Mentzel T, et al. Olaparib and Temozolomide in Desmoplastic Small Round Cell Tumors: A Promising Combination In Vitro and In Vivo. J Cancer Res Clin Oncol (2020) 146(7):1659-70. doi: 10.1007/s00432-020-03211-z

140. Modak S, Gerald W, Cheung NK. Disialoganglioside GD2 and a Novel Tumor Antigen: Potential Targets for Immunotherapy of Desmoplastic Small Round Cell Tumor. Med Pediatr Oncol (2002) 39(6):547-51. doi: 10.1002/mpo.10151

141. Modak S, Zanzonico P, Grkovski M, Slotkin EK, Carrasquillo JA, Lyashchenko SK, et al. B7H3-Directed Intraperitoneal Radioimmunotherapy With Radioiodinated Omburtamab for Desmoplastic Small Round Cell Tumor and Other Peritoneal Tumors: Results of a Phase I Study. J Clin Oncol (2020) 38(36): Jco2001974. doi: 10.1200/JCO.20.01974

142. Dobrenkov K, Ostrovnaya I, Gu J, Cheung IY, Cheung NK. Oncotargets GD2 and GD3 are Highly Expressed in Sarcomas of Children, Adolescents, and Young Adults. Pediatr Blood Cancer (2016) 63(10):1780-5. doi: 10.1002/ pbc. 26097

143. Johnson DB, Sullivan RJ, Menzies AM. Immune Checkpoint Inhibitors in Challenging Populations. Cancer (2017) 123(11):1904-11. doi: 10.1002/ cncr.30642

144. Bulbul A, Shen JP, Xiu J, Tamayo P, Husain H. Genomic and Proteomic Alterations in Desmoplastic Small Round Blue-Cell Tumors. JCO Precis Oncol (2018) 2:PO.17.00170. doi: 10.1200/PO.17.00170

145. Fine RL, Shah SS, Moulton TA, Yu IR, Fogelman DR, Richardson M, et al. Androgen and C-Kit Receptors in Desmoplastic Small Round Cell Tumors Resistant to Chemotherapy: Novel Targets for Therapy. Cancer Chemother Pharmacol (2007) 59(4):429-37. doi: 10.1007/s00280-006-0280-z

146. Mazuryk M, Paterson AH, Temple W, Arthur K, Crabtree T, Stewart DA. Benefit of Aggressive Multimodality Therapy With Autologous Stem Cell Support for Intra-Abdominal Desmoplastic Small Round Cell Tumor. Bone Marrow Transplant (1998) 21(9):961-3. doi: 10.1038/sj.bmt.1701220

147. Bailey K, Roth M, Weiser D, Gill J. High-Dose Chemotherapy With Stem Cell Rescue in Desmoplastic Small Round Cell Tumor: A Single-Institution
Experience and Review of the Literature. Sarcoma (2018) 2018:1948093. doi: $10.1155 / 2018 / 1948093$

148. Cook RJ, Wang Z, Arora M, Lazarus HM, Kasow KA, Champagne MA, et al. Clinical Outcomes of Patients With Desmoplastic Small Round Cell Tumor of the Peritoneum Undergoing Autologous HCT: A CIBMTR Retrospective Analysis. Bone Marrow Transplant (2012) 47(11):1455-8. doi: 10.1038/ bmt.2012.57

149. Arends J, Bachmann P, Baracos V, Barthelemy N, Bertz H, Bozzetti F, et al. ESPEN Guidelines on Nutrition in Cancer Patients. Clin Nutr (2017) 36 (1):11-48. doi: 10.1016/j.clnu.2016.07.015

150. Hayes-Jordan AA, Coakley BA, Green HL, Xiao L, Fournier KF, Herzog CE, et al. Desmoplastic Small Round Cell Tumor Treated With Cytoreductive Surgery and Hyperthermic Intraperitoneal Chemotherapy: Results of a Phase 2 Trial. Ann Surg Oncol (2018) 25(4):872-7. doi: 10.1245/ s10434-018-6333-9

151. Zhang G, Liu G, Zhao D, Cui X, Li G. Desmoplastic Small Round Cell Tumor of the Abdomen and Pelvis: Clinicopathological Characters of 12 Cases. ScientificWorldJournal (2014) 2014:549612. doi: 10.1155/2014/549612

Conflict of Interest: The authors declare that the research was conducted in the absence of any commercial or financial relationships that could be construed as a potential conflict of interest.

Publisher's Note: All claims expressed in this article are solely those of the authors and do not necessarily represent those of their affiliated organizations, or those of the publisher, the editors and the reviewers. Any product that may be evaluated in this article, or claim that may be made by its manufacturer, is not guaranteed or endorsed by the publisher.

Copyright (C) 2021 Wei, Shu, Zhou, Liu, Chen and Qiu. This is an open-access article distributed under the terms of the Creative Commons Attribution License (CC BY). The use, distribution or reproduction in other forums is permitted, provided the original author(s) and the copyright owner(s) are credited and that the original publication in this journal is cited, in accordance with accepted academic practice. No use, distribution or reproduction is permitted which does not comply with these terms. 